\title{
Impact of change in climate and policy from 1988 to 2007 on environmental and microbial variables at the time series station Boknis Eck, Baltic Sea
}

\author{
H.-G. Hoppe, H. C. Giesenhagen, R. Koppe, H.-P. Hansen, and K. Gocke \\ GEOMAR Helmholtz-Centre for Ocean Research Kiel, Wischhofstrasse 1-3, 24148 Kiel, Germany \\ Correspondence to: H.-G. Hoppe (hhoppe@geomar.de)
}

Received: 25 October 2012 - Published in Biogeosciences Discuss.: 18 December 2012

Revised: 19 April 2013 - Accepted: 24 April 2013 - Published: 4 July 2013

\begin{abstract}
Phytoplankton and bacteria are sensitive indicators of environmental change. The temporal development of these key organisms was monitored from 1988 to the end of 2007 at the time series station Boknis Eck in the western Baltic Sea. This period was characterized by the adaption of the Baltic Sea ecosystem to changes in the environmental conditions caused by the conversion of the political system in the southern and eastern border states, accompanied by the general effects of global climate change. Measured variables were chlorophyll, primary production, bacteria number, -biomass and -production, glucose turnover rate, macro-nutrients, $\mathrm{pH}$, temperature and salinity. Negative trends with time were recorded for chlorophyll, bacteria number, bacterial biomass and bacterial production, nitrate, ammonia, phosphate, silicate, oxygen and salinity while temperature, $\mathrm{pH}$, and the ratio between bacteria numbers and chlorophyll increased. Strongest reductions with time occurred for the annual maximum values, e.g. for chlorophyll during the spring bloom or for nitrate during winter, while the annual minimum values remained more stable. In deep water above sediment the negative trends of oxygen, nitrate, phosphate and bacterial variables as well as the positive trend of temperature were similar to those in the surface while the trends of salinity, ammonia and silicate were opposite to those in the surface. Decreasing oxygen, even in the surface layer, was of particular interest because it suggested enhanced recycling of nutrients from the deep hypoxic zones to the surface by vertical mixing. The long-term seasonal patterns of all variables correlated positively with temperature, except chlorophyll and salinity. Salinity correlated negatively with all bacterial variables (as well as precipitation) and pos-
\end{abstract}

itively with chlorophyll. Surprisingly, bacterial variables did not correlate with chlorophyll, which may be inherent with the time lag between the peaks of phytoplankton and bacteria during spring. Compared to the 20 -yr averages of the environmental and microbial variables, the strongest negative deviations of corresponding annual averages were measured about ten years after political change for nitrate and bacterial secondary production $(\sim-60 \%)$, followed by chlorophyll $(-50 \%)$ and bacterial biomass $(-40 \%)$. Considering the circulation of surface currents in the Baltic Sea we interpret the observed patterns of the microbial variables at the Boknis Eck time series station as a consequence of the improved management of water resources after 1989 and - to a minor extent - the trends of the climate variables salinity and temperature.

\section{Introduction}

Microbes provide the nutritional base of the marine food web. Changes in the productivity and biomass and in the interaction of the autotrophic and heterotrophic components of the microbial community affect the marine element cycles and - due to cascading - also the higher food chain levels (Wohlers et al., 2009; Zöllner et al., 2009). The development of autotrophic and heterotrophic microbes is influenced by climate, the prevailing hydrological conditions and other factors such as anthropogenic eutrophication and pollution. The balance between these two components of the microbial community influences the contribution of living organisms to the $\mathrm{CO}_{2}$ exchange between the ocean and the atmosphere and 
the transfer of the photosynthetic biomass production into the microbial or the herbivorous-carnivorous food chain.

Deviation of the balance between autotrophic and heterotrophic microbial communities from a former level caused by climate change and/or other factors can be assessed and possibly predicted by the trends of the individual components derived from long-term time series studies. The time series at the coastal station "Boknis Eck" in the western Baltic Sea, starting in the year 1957, is one of the longest monitoring series ever made (Krey et al., 1978; Bange, 2010; Bange et al., 2011), together with the series at the "Helgoland roads" station in the North Sea, in operation since 1962 (Franke et al., 2004; Gerdts et al., 2004; Wiltshire et al., 2010). Other coastal long-term studies are presented by, e.g. LOICZ (Land-Ocean Interactions in the Coastal Zone), the "Saanich Inlet Time Series" or the "NIO Goa, India - CaTS (Candolim Time Series Station)". In the Baltic Sea, the international monitoring of the border states was organized by the Baltic Marine Environment Protection Commission, HELCOM, since 1979 (e.g. Wasmund et al., 2006; Nausch et al., 2011a). Frequently the development and extent of $\mathrm{H}_{2} \mathrm{~S}$ zones in the deep basins of the Baltic Sea were regarded as indicators of ecosystem healthiness. However, it turned out that these factors did not only depend on eutrophication and pollution but even more on the duration of water stagnation periods between two events of oxygenation by North Sea water intrusion into the Baltic Sea.

To our knowledge, the data of Boknis Eck represent the only long-term series on the development of bacterial numbers and production in the Baltic Sea, except a time series of bacterial growth performed from 1994 to 2010 in the Bothnian Bay (Wikner, 2011) but this was restricted to the water layer below the pycnocline. At the Boknis Eck station the measurement of bacterial variables was included into the standard monitoring program as of 1985 . Here we report only on results of the twenty-year-period from 1988 to the end of 2007 , because during this period measurements were conducted strictly by the same methods and even by the same operators. This is an important premise for the consistency of the data set and the reliability of conclusions and predictions.

During our time series study changes occurred in the political systems of several border states of the Baltic Sea, which were combined with dramatic ecological, socio-economical, agricultural and industrial developments. The after-effects of political change in 1989 led to an improvement of seawater quality, starting in the central and eastern parts of the Baltic Sea. Due to the current system and the short turnover time of the water volume these improvements spread all over the Baltic Sea (HELCOM, 2009a), arriving finally at the most western Boknis Eck area. It was the aim of the study to determine the trends and ranges of environmental and microbial variables at the time series station Boknis Eck for the twenty years period after political change and to specify the relative influences of changes in climate and policy on the system -

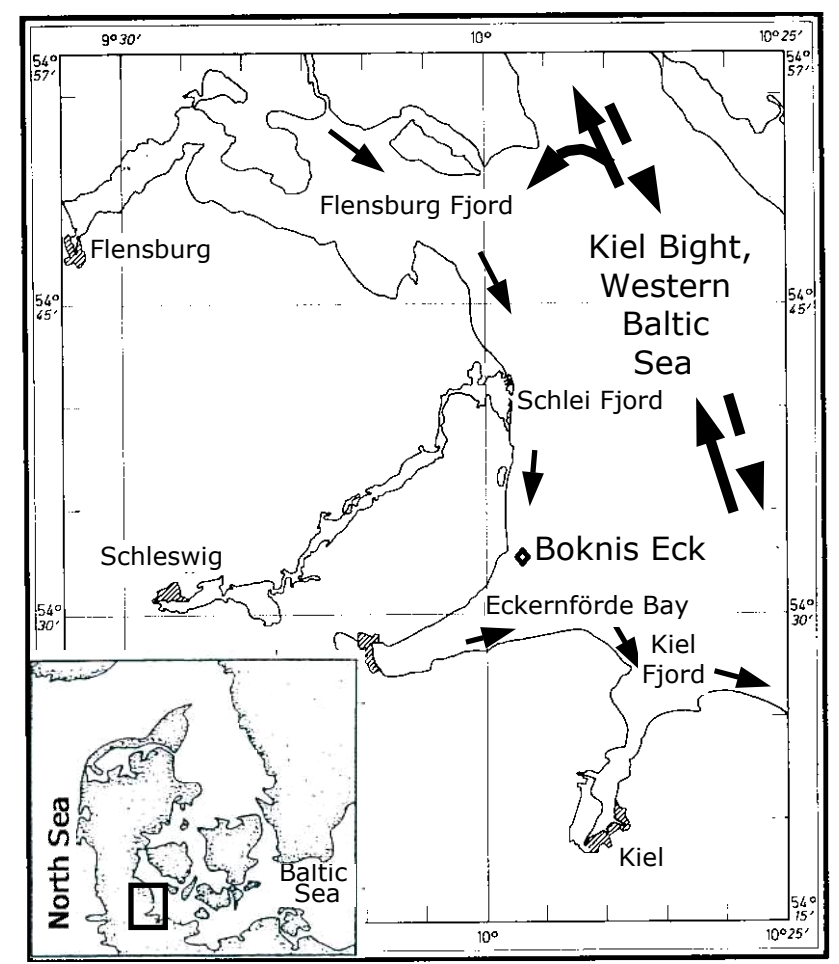

Fig. 1. Location (diamond) of the time series station Boknis Eck in the Kiel Bight, western Baltic Sea. Arrows indicate the predominant direction of surface currents. Dashed arrows indicate the direction of North Sea water currents in the deep.

in comparison with other regions of the Baltic Sea and the adjacent North Sea.

\section{Study area, sampling and methods}

\subsection{Study area and sampling}

The Baltic Sea is a semi-enclosed brackish sea in the moderate climate zone, characterized by a limited water exchange with the more saline North Sea and large inputs of fresh water by rivers. The "Boknis Eck" time series station is situated $1 \mathrm{~km}$ off the coast at $54^{\circ} 31.77 \mathrm{~N}, 10^{\circ} 02.36 \mathrm{E}$ in the Kiel Bight, which is part of the western Baltic Sea (Fig. 1). The water depth is ca. $28 \mathrm{~m}$. The Kiel Bight lies in the transition zone between the North Sea and the central Baltic Sea. These conditions implicate strong seasonal variability of temperature and salinity at the station. Thermohaline stratification is established during summer, followed by vertical mixing of the water column during fall and winter. Chemical and biological variables at the station are influenced by these conditions and additionally by organic/inorganic matter inputs from land, rivers and air. The land-side region near the station is densely populated, suggesting a heavy load of treated sewage. However, only small rivers enter the coastal region. The main sources of freshwater input into the Baltic Sea are 
the big streams Oder, Wisła and Neva. These are situated in the densely populated central and eastern parts of the Baltic Sea coast. This means that mediated by the Baltic Sea current system and circulation within the Kiel Bight (Fig. 1), the environmental conditions at the time series station are not only determined by local factors but indirectly also by remote factors.

Water samples were taken with a Niskin sampler at monthly intervals from 1988 until the end of 2007 in 1, 2, $5,10,15 \mathrm{~m}$ water depth and about $2 \mathrm{~m}$ above sediment. More frequent sampling in certain months and depths and for certain variables was conducted in the years 1992 and 1993 and from 1996 to 1998 . Here we report only values from the $1 \mathrm{~m}$ or $2 \mathrm{~m}$ surface layer and the deepest sampling. Variables of measurement were salinity, temperature, oxygen, nitrate, ammonia, phosphate, silicate as well as chlorophyll, primary production, bacteria number, bacterial biomass, bacterial secondary production and glucose turnover rate.

\subsection{Temperature, salinity, oxygen, $\mathrm{pH}$ and nutrients}

Temperature and salinity were measured by WTW-probe (WTW Wissenschaftlich-Technische Werkstätten GmbH, Weilheim, Germany). Oxygen was determined by the Winkler technique or WTW-oxygen probe. $\mathrm{pH}$ was measured with electrodes and calibrated against standard NBS buffer solutions. Nutrients (nitrate, nitrite, ammonia, phosphate, silicate) were measured photometrically by standard techniques according to Hansen and Koroleff (1999).

\subsection{Chlorophyll $a$ concentration and primary production}

Chlorophyll was determined fluorometrically after filtration on glass fiber filters and ethanol or acetone extraction according to HELCOM (1991). This parameter is conventionally used as a rough measure of phytoplankton biomass, which in turn is regarded as a proxy for bacterial substrate supply.

Potential primary production was calculated from $\left[{ }^{14} \mathrm{C}\right]-$ bicarbonate $(4 \mu \mathrm{Ci}$ per $25 \mathrm{~mL}$ bottle) uptake. The bottles were covered with neutral filters adjusted from $100 \%$ to $10 \%$ of natural light according to the sampling depths. They were incubated in an incubator (Gargas, 1975) at in situ surface water temperature and constant light for about $3 \mathrm{~h}$. Two replicates and 1 dark blank were performed. After incubation the samples were filtered on $0.2 \mu \mathrm{m}$ cellulose acetate filters (Sartorius) fumed with $\mathrm{HCl}$ and radio-assayed in a Packard Tricarb scintillation counter. The $\mathrm{CO}_{2}$ content of the brackish water was calculated from measurements of $\mathrm{pH}$, salinity, temperature and alkalinity of the samples. Potential primary production is presented as $m g \mathrm{Cm}^{-3} \mathrm{~h}^{-1}$. The method and the equation for calculating potential primary production are precisely described in HELCOM (1983).

\subsection{Bacteria number, biomass, growth and glucose turnover rate}

For the determination of bacteria numbers (cells $\mathrm{mL}^{-1}$ ) aliquots of $100 \mathrm{~mL}$ of water were fixed with formaldehyde (final concentration of $2 \% \mathrm{vol} / \mathrm{vol}$ ) and stored at $4{ }^{\circ} \mathrm{C}(\mathrm{Hob}-$ bie et al., 1977). Filtration of 1 to $10 \mathrm{~mL}$ aliquots onto black $0.2 \mu \mathrm{m}$ polycarbonate filters was performed within 7 days after fixation. Cells were stained with acridine orange $\left(150 \mu \mathrm{g} \mathrm{mL}^{-1}\right)$ and frozen at $-18^{\circ} \mathrm{C}$ until being counted under an epifluorescence microscope (Axioplan, Carl Zeiss, Germany) at $1000 \times$ magnification, using a NewPorton G12 Grid (Graticules LTD, UK). About twenty grids or at least 400 cells were counted per sample. Freezing did not change bacteria counts within a period of half a year. Bacteria cell volume was calculated from length and width measurements of 50 randomly selected cells on a New Porton grid. Individual bacterial biomass was determined according to the nonlinear function of Simon and Azam (1989):

$\begin{aligned} G_{\mathrm{P}} & =88.6 \times V^{-0.59} \\ G_{\mathrm{C}} & =G_{\mathrm{P}} \times 1.04878,\end{aligned}$

where $G_{\mathrm{P}}$ means cellular protein content, $V$ means cell volume and $G_{\mathrm{C}}$ cellular carbon content.

Bacterial growth was derived from $\left[{ }^{3} \mathrm{H}\right]$-methyl-thymidine uptake (Thy $\mathrm{u}_{\mathrm{u}}$ ) according to Fuhrman and Azam (1982) using a final concentration of $5.79 \mathrm{nM}$ of $\left[{ }^{3} \mathrm{H}\right]$-methyl-thymidine. Triplicate $10 \mathrm{~mL}$ samples and one formalin fixed control were incubated in the dark for 2 to $4 \mathrm{~h}$ in thermo-containers at in situ temperature $\left( \pm 1^{\circ} \mathrm{C}\right)$. After fixation with formaldehyde (final concentration of $1 \% \mathrm{vol} / \mathrm{vol}$ ) the bacteria were collected on $0.2 \mu \mathrm{m}$ polycarbonate filters (Poretics) and rinsed 10 times with $1 \mathrm{~mL}$ ice-cold $5 \%$ trichloroacetic acid (TCA) solution. Samples were radio-assayed in a Packard Tricarb counter with Lumagel as scintillation cocktail. Measurements of bacterial growth are presented in terms of pmol $\mathrm{L}^{-1} \mathrm{~h}^{-1}$ of bacterial $\left[{ }^{3} \mathrm{H}\right]$-methyl-thymidine uptake. The amount of thymidine uptake ( $\mathrm{Thy}_{\mathrm{u}}$ ) was calculated according to the equation:

$\mathrm{Thy}_{\mathrm{u}}=\mathrm{dpm}_{\mathrm{corr}} \times V^{-1} \times t^{-1} \times \mathrm{SA}^{-1}$,

where $\mathrm{dpm}_{\text {corr }}$ means disintegrations per minute corrected by the control, $V$ means the volume of the sample in $\mathrm{mL}, t$ the incubation time in $\mathrm{h}$ and SA the specific activity of $\left[{ }^{3} \mathrm{H}\right]$ methyl-thymidine in $\mathrm{dpm} \mathrm{fmol}^{-1}$.

The turnover rate of glucose was determined by the addition of $0.04 \mu \mathrm{Ci}$ of uniformly labelled ${ }^{14} \mathrm{C}$-glucose to triplicate $20 \mathrm{~mL}$ water samples. After incubation for 2 to $4 \mathrm{~h}$ at in situ temperature, the bacteria were collected on $0.2 \mu \mathrm{m}$ cellulose-acetate filters and radio-assayed in a Packard Tricarb counter. The turnover rate of added glucose is presented as $\% \mathrm{~d}^{-1}$ and regarded as a proxy for the turnover of the natural pool of glucose. 
Table 1. Values or concentrations (averages) of selected variables in deep anoxic, hypoxic or oxic water compared to corresponding patterns derived from oxic or hypoxic surface water.

\begin{tabular}{|c|c|c|c|c|c|c|c|c|c|c|c|c|c|c|}
\hline & $N$ & $\begin{array}{r}\text { Temp. } \\
{ }^{\circ} \mathrm{C}\end{array}$ & $\begin{array}{r}\text { Salinity } \\
\text { PSU }\end{array}$ & $\begin{array}{r}\text { Oxygen } \\
\mu \mathrm{M}\end{array}$ & $\mathrm{pH}$ & $\begin{array}{r}\mathrm{Si} \\
\mu \mathrm{M}\end{array}$ & $\begin{array}{r}\mathrm{NH}_{4} \\
\mu \mathrm{M}\end{array}$ & $\begin{array}{r}\mathrm{NO}_{2} \\
\mu \mathrm{M}\end{array}$ & $\begin{array}{r}\mathrm{NO}_{3} \\
\mu \mathrm{M}\end{array}$ & $\begin{array}{r}\mathrm{PO}_{4} \\
\mu \mathrm{M}\end{array}$ & $\begin{array}{l}\text { Chloro. } \\
\mu g L^{-1}\end{array}$ & $\begin{array}{r}\text { Bacteria } \\
\text { number } \\
10^{6} \mathrm{~mL}^{-1}\end{array}$ & $\begin{array}{r}\text { Bacteria } \\
\text { biomass } \\
\mu \mathrm{gCL}^{-1}\end{array}$ & $\begin{array}{r}\text { Thymidine } \\
\text { uptake } \\
\mathrm{pMh}^{-1}\end{array}$ \\
\hline \multicolumn{15}{|l|}{ Bottom layer } \\
\hline anoxic & 10 & 12.15 & 21.43 & 0.0 & 7.4 & 77.6 & 15.33 & 0.28 & 1.36 & 8.40 & 0.43 & 2.00 & 23.0 & 18.4 \\
\hline hypoxic, $\mathrm{O}_{2}>0-10 \mu \mathrm{M}$ & 17 & 11.29 & 22.47 & 5.8 & 7.4 & 63.6 & 10.97 & 0.29 & 1.44 & 6.01 & 0.36 & 1.62 & 21.0 & 18.0 \\
\hline hypoxic, $\mathrm{O}_{2} 10-150 \mu \mathrm{M}$ & 110 & 9.49 & 22.24 & 77.1 & 7.5 & 44.6 & 5.16 & 0.29 & 4.92 & 1.56 & 0.90 & 1.54 & 15.2 & 12.0 \\
\hline oxic, $\mathrm{O}_{2}>150 \mu \mathrm{M}$ & 156 & 5.07 & 21.17 & 263.0 & 8.0 & 19.2 & 4.06 & 0.46 & 6.41 & 0.81 & 2.01 & 1.63 & 17.1 & 9.88 \\
\hline all data & 292 & 7.20 & 21.70 & 168.0 & 7.8 & 33.4 & 5.32 & 0.38 & 5.33 & 1.62 & 1.49 & 1.63 & 17.5 & 12.5 \\
\hline \multicolumn{15}{|l|}{ Surface layer } \\
\hline hypoxic, $\mathrm{O}_{2}>0-150 \mu \mathrm{M}$ & 5 & 14.03 & 19.38 & 115.2 & 7.5 & 36.9 & 1.76 & 0.19 & 0.93 & 1.82 & 2.27 & 1.06 & 13.0 & 21.2 \\
\hline $\mathrm{O}_{2}>150 \mu \mathrm{M}$ & 287 & 9.94 & 16.60 & 329.6 & 8.2 & 7.9 & 0.96 & 0.18 & 1.84 & 0.39 & 2.82 & 1.72 & 22.2 & 13.2 \\
\hline all data & 292 & 10.01 & 16.65 & 325.9 & 8.2 & 8.4 & 0.98 & 0.18 & 1.82 & 0.41 & 2.81 & 1.71 & 22.0 & 13.3 \\
\hline
\end{tabular}

\subsection{Data analysis}

Statistical analysis of the data set was performed by using Sigma-Stat and Sigma-Plot analytical tools (test of normal distribution by Kolmogorov-Smirnov test, non-random Spearman's Rank distribution, Pearson and Spearman multiple correlation, linear and polynomial Regression and MannWhitney Rank Sums test.

Regression lines in the figures represent significant regressions or insignificant trends. In addition to the linear regressions (based on all data on the plot) the trends of the annual maximal and minimal values of variables, derived from the three highest or lowest values per year, respectively, were calculated. Furthermore, polynomial regressions were considered in order to detect specific temporal patterns of the selected variables. We interpreted the mostly negative linear trends of variables as a consequence of the after-effects of political change, while we attributed the curves of the polynomial trends to changes and variability of climatic factors.

\subsection{Figures}

The Figs. 2 to 16 are compiled on separate pages at the start of the chapter "Discussion". This unusual form of presentation was chosen because it was nearly impossible to arrange many figures within the short "Results" sub-chapters without disrupting the text. Furthermore, even more important, this form of presentation appeared to be adequate because the figures are frequently addressed and compared in the "Results" as well as in the "Discussion" chapters. The reader does not need to look very far to find the figure in question.

\section{Results}

\subsection{Salinity, temperature and oxygen}

Surface salinity and oxygen decreased slightly during the $20 \mathrm{yr}$ of observation while temperature increased (derived from linear regression trends, all data, Figs. 2, 5). Figures are shown on separate pages at the start of the "Discussion". More information on the placement of figures is provided in Sect. 2.6. In detail (polynomial regressions), salinity and oxygen showed roughly similar trends while temperature behaved antagonistically to the former. In addition to the linear regressions (derived from all data) the trends of the annual maxima and minima values of variables were plotted in order to identify the influence of seasons on the general trend.

Concerning surface salinity, maximal values (during winter) decreased slightly, while the minimal values (during summer) slightly increased. In contrast, maximal temperatures during summer increased, while the minimal values during winter even decreased (Fig. 2). The general trends of salinity and temperature (derived from all data) were mainly determined by the trends of the maximal values of the respective variable.

In deep water, the average values of salinity (22 PSU) and temperature $\left(7^{\circ} \mathrm{C}\right)$ were higher or lower than those at the surface (17 PSU and $10^{\circ} \mathrm{C}$, respectively, Table 1) and showed a slight increase over the period of study (Table 2).

The relationship between surface temperature and salinity (Fig. 3) at the station exhibited the typical pattern of the Kiel Bight where high salinity is combined with low temperature during winter and low salinity with high temperature during summer.

A comparison of the trends of linear and polynomial regressions of sea surface temperature at Boknis Eck (Fig. 2) with those of air temperature from a remote, more eastern station (meteorological station of Greifswald near the Oder estuary, Fig. 4) exhibited roughly similar patterns, while the trends of precipitation at the remote station (Fig. 4) behaved 
roughly antagonistic to those of sea surface salinity at Boknis Eck (Fig. 2). Figure 4 is representative for the ranges and relationships of temperature and precipitation also at other places in the southern and western Baltic region. The data base of this figure was provided by WetterKontor $\mathrm{GmbH}$, 55218 Ingelheim, http://www.wetterkontor.de/. The original data are from Deutscher Wetterdienst, 63067 Offenbach, http://www.dwd.de.

\subsection{Oxygen and $\mathrm{pH}$}

A general decrease of the surface oxygen concentration was recorded during the past $20 \mathrm{yr}$ at Boknis Eck (Fig. 5, all data), although, early in the year, the maximal values of oxygen increased. Occasionally, five times during late summer, oxygen dropped down to hypoxic conditions at the surface (Table 1).

The oxygen concentration of surface water accelerated slightly with increasing salinity during the winter months and showed a strong decreasing trend with rising temperature during summer (Fig. 6a, b). The correlation of oxygen with salinity was insignificant while there was a highly significant negative correlation with temperature (Table $3 b$ ).

In deep water the annual periods of hypoxic conditions (below $150 \mu \mathrm{M} \mathrm{O}_{2}$ ) prolonged during the $20 \mathrm{yr}$ from about 5 to 7 months (not shown). The average oxygen concentration during these periods was about $77 \mu \mathrm{M}$ (Table 1), increasing slightly together with salinity.

The values of $\mathrm{pH}$ rose slightly over the reduced period of measurement (only $10 \mathrm{yr}$ from 1988 to 1998). This surprising observation is concerned later in the discussion.

\subsection{Inorganic nutrients}

Macro-nutrients, such as nitrate, ammonia, phosphate and silicate create the conditions for phytoplankton growth (besides of light). The input of these nutrients into the Baltic Sea derives from rivers, sewage plants, air and the sediment. A linear decrease over the past $20 \mathrm{yr}$ was recorded for ammonia, nitrate, phosphate and silicate with distinctly different slopes (Fig. 7a-d). In detail (polynomial regressions) all variables showed the same temporal patterns with a deep depression during the late nineties and an increase at the beginning of the new century, roughly coinciding with the patterns of salinity and oxygen (Figs. 2, 5). The developments of the annual winter maxima of nutrients during the study period showed an increase for silicate while ammonia, phosphate and nitrate declined. Summer minima were very low and decreased for silicate and phosphate while ammonia and nitrate slightly increased (Fig. 7a-d).

The seasonal relationships between salinity and the different nutrients showed strong increases of the nutrient concentrations during the months of high salinity in winter due to vertical mixing and reduced consumption of nutrients by phytoplankton (Fig. 8a). All nutrients dropped down to very low concentrations during summer (nitrate first, seems to be the limiting source). Silicate also decreased but remained relatively high during summer (Fig. 8b).

Nutrient concentrations in the deep hypoxic or completely anoxic water (about $2 \mathrm{~m}$ above sediment) during the annual period of thermohaline stratification were considerably higher than during periods of oxygenation after vertical mixing. During the autumnal period of vertical mixing and upwelling intrusion of deep water into the surface layer caused occasionally hypoxic conditions in the latter accompanied by a strong increase of all nutrients except nitrate (Table 1). The recruitment of stored nutrients from anoxic sediments counteracts the efforts of waste water purification on land side (cf. discussion).

\subsection{Chlorophyll $a$ concentration and potential primary production}

The phytoplankton variables exhibited strongly negative trends over the period of investigation. The trend of chlorophyll was statistically significant. Decrease was slightly steeper for primary production than for chlorophyll (Fig. 9, Table 2). Unfortunately it was not possible to measure primary production over the whole period. The polynomial patterns of chlorophyll behaved roughly antagonistic to those of the nutrients (cf. Fig. 7a-d) and similar to those of the bacterial variables (cf. Fig. 12).

The development of chlorophyll during the spring bloom (maximal values) decreased significantly during the past $20 \mathrm{yr}$ while there was only a small decrease of the winter minima (Fig. 10). There was a very deep depression of chlorophyll during the early years of the new century about ten years after political change, coinciding with relatively high values of salinity and narrow annual ranges of salinity and oxygen (cf. Figs. 2, 5).

The seasonal relationships between chlorophyll and the nutrients showed a decrease of ammonia (exhausting first) and nitrate at increasing chlorophyll concentrations, while phosphate remained rather constant and silicate even increased (Fig. 11).

\subsection{Bacteria number, bacterial growth, biomass and glucose turnover rate}

Bacteria numbers and bacterial growth (Thymidine uptake) showed negative trends (linear regressions) during the past $20 \mathrm{yr}$ (Fig. 12). Bacterial growth declined more than bacteria numbers. The seasonal variability of the bacterial data was very high due to the change in nutrition from winter to phytoplankton spring bloom conditions and the seasonal variations in temperature and grazing pressure. In detail (polynomial regressions), deep depressions occurred during the early 90th and at the beginning of the new century (Figs. 12, 13). Shapes of the curves of bacterial variables were in general similar to those of chlorophyll and primary production (compare Fig. 12 to Fig. 9). 
Table 2. Regression analysis of the data set showing the development of selected variables over the $20 \mathrm{yr}$ period of observation. $\mathrm{BN}=\mathrm{Bacteria}$ number, Thy $=$ Thymidine uptake (proxy of bacterial growth), Chl = Chlorophyll $a$. The variables are grouped according to their negative or positive degree of $\%$ change per year, for surface or bottom waters, respectively. Bold $=$ statistically significant, regular $=$ trend, statistically insignificant.

\begin{tabular}{|c|c|c|c|c|c|}
\hline \multicolumn{6}{|c|}{ Regressions, Time Series Station Boknis Eck, Western Baltic Sea } \\
\hline Variable & $N$ & Regression equation & Fit & Probability & $\begin{array}{l}\% \text { change } \\
\text { per year }\end{array}$ \\
\hline \multicolumn{6}{|l|}{ Surface layer } \\
\hline Nitrate $[\mu \mathrm{M}]$ & 296 & $y=-0.00029 x+2.82$ & $r^{2}=\mathbf{0 . 0 3 1}$ & $P=0.003$ & -3.75 \\
\hline Bact. biomass $\left[\mu \mathrm{C} \mathrm{CL}^{-1}\right.$ ] & 284 & $y=-0.0034 x+33.88$ & $r^{2}=0.156$ & $\boldsymbol{P}=<\mathbf{0 . 0 0 1}$ & -3.62 \\
\hline Phosphate $[\mu \mathrm{M}]$ & 293 & $y=-0.000038 x+0.48$ & $r^{2}=0.032$ & $P=0.002$ & -2.89 \\
\hline Prim. production $\left[\mathrm{mg} \mathrm{Cm}^{-3} \mathrm{~h}^{-1}\right]$ & 160 & $y=-0.00069 x+10.54$ & $r^{2}=0.0073$ & $P=0.283$ & -2.39 \\
\hline Chlorophyll $\left[\mu \mathrm{gL}^{-1}\right]$ & 285 & $y=-0.00019 x+3.52$ & $r^{2}=0.025$ & $P=0.007$ & -1.97 \\
\hline Nitrite $[\mu \mathrm{M}]$ & 296 & $y=-0.000012 x+0.23$ & $r^{2}=0.0073$ & $P=0.143$ & -1.90 \\
\hline Thy/BN & 272 & $y=-0.00030 x+8.26$ & $r^{2}=0.011$ & $P=0.082$ & -1.33 \\
\hline Thymidine uptake, Thy. $\left[\mathrm{pMh}^{-1}\right]$ & 273 & $y=-0.00026 x+12.27$ & $r^{2}=0.003$ & $P=0.365$ & -0.77 \\
\hline Silicate $[\mu \mathrm{M}]$ & 295 & $y=-0.00018 x+9.03$ & $r^{2}=0.0014$ & $P=0.528$ & -0.72 \\
\hline Ammonia $[\mu \mathrm{M}]$ & 294 & $y=-0.000015 x+0.93$ & $r^{2}=0.0002$ & $P=0.832$ & -0.59 \\
\hline Bacteria number, BN [cells $\mathrm{mL}^{-1}$ ] & 285 & $y=-27.96 x+1817186$ & $r^{2}=0.0024$ & $P=0.406$ & -0.56 \\
\hline Oxygen $[\mu \mathrm{M}]$ & 293 & $y=-0.0029 x+335.85$ & $r^{2}=0.010$ & $P=0.085$ & -0.32 \\
\hline Salinity [PSU] & 282 & $y=-0.000064 x+16.86$ & $r^{2}=0.0019$ & $P=0.470$ & -0.14 \\
\hline Glucose turnover [\% $\mathbf{d}^{-1}$ ] & 124 & $y=0.015 x+31.99$ & $r^{2}=0.043$ & $P=0.020$ & 17.11 \\
\hline BN/Chlorophyll & 279 & $y=0.097 x+715.6$ & $r^{2}=0.029$ & $P=0.004$ & 4.95 \\
\hline Thy/Chlorophyll & 271 & $y=0.00044 x+5.04$ & $r^{2}=0.011$ & $P=0.080$ & 3.19 \\
\hline Temperature $\left[{ }^{\circ} \mathrm{C}\right]$ & 283 & $y=0.00025 x+9.17$ & $r^{2}=0.0062$ & $P=0.185$ & 1.00 \\
\hline pH & 118 & $y=0.000086 x+8.07$ & $r^{2}=0.124$ & $P \leq 0.001$ & 0.39 \\
\hline \multicolumn{6}{|l|}{ Bottom layer } \\
\hline Nitrate $[\mu \mathrm{M}]$ & 294 & $y=-0.00034 x+6.50$ & $r^{2}=0.0278$ & $P=0.004$ & -1.91 \\
\hline Oxygen $[\mu \mathrm{M}]$ & 292 & $y=-0.0079 x+195.00$ & $r^{2}=0.0168$ & $P=0.027$ & -1.48 \\
\hline Bacteria number, BN [cells $\mathbf{m L}^{-1}$ ] & 292 & $y=-47.82 x+1631854$ & $r^{2}=0.016$ & $P=0.042$ & -1.07 \\
\hline Phosphate $[\mu \mathrm{M}]$ & 293 & $y=-0.000023 x+1.70$ & $r^{2}=0.0004$ & $P=0.734$ & -0.49 \\
\hline Thymidine uptake, Thy. $\left[\mathrm{pMh}^{-1}\right]$ & 238 & $y=-0.000005 x+9.66$ & $r^{2}=0.00001$ & $P=0.990$ & -0.02 \\
\hline Ammonia $[\mu \mathrm{M}]$ & 292 & $y=0.00042 x+3.89$ & $r^{2}=0.0185$ & $P=\mathbf{0 . 0 2 0}$ & 3.90 \\
\hline Salinity [PSU] & 280 & $y=0.00020 x+21.00$ & $r^{2}=0.0313$ & $P=0.003$ & 3.51 \\
\hline Silicate $[\mu \mathrm{M}]$ & 294 & $y=0.00071 x+30.95$ & $r^{2}=0.0048$ & $P=0.236$ & 0.84 \\
\hline pH & 117 & $y=0.00015 x+7.54$ & $r^{2}=0.182$ & $P \leq \mathbf{0 . 0 0 1}$ & 0.72 \\
\hline Temperature $\left[{ }^{\circ} \mathrm{C}\right]$ & 283 & $y=0.00011 x+6.85$ & $r^{2}=0.0033$ & $P=0.337$ & 0.59 \\
\hline
\end{tabular}

As a result of decreasing bacterial numbers and growth, the biomass of bacteria dropped drastically. On the other hand, the turnover rate of glucose was one of the rare parameters which increased during the study (Table 2). Because the glucose turnover rate depends on the natural pool of glucose, the increase of glucose turnover suggests a strong reduction of the pool size over the period of investigation.

The development of the maximal values of bacteria numbers showed a strong decrease, particularly during the late spring/early summer situation (the degradation phase after the phytoplankton spring bloom), while the minima during winter increased slightly (Fig. 13).

Bacterial growth in relation to salinity decreased (Fig. 14a) while it increased with temperature (Fig. 14b) and hardly reacted to the chlorophyll concentration (Fig. 14c) due to the time lag between the phytoplankton spring bloom and the development of bacteria in the post-bloom phase.
In deep water bacteria numbers, biomass and growth rose during anoxic and hypoxic periods compared to oxic periods. When vertical mixing caused hypoxic conditions in the surface layer, bacteria numbers and biomass decreased while bacterial growth was accelerated (Table 1). The long-term trends over $20 \mathrm{yr}$ showed that bacteria numbers in the deep decreased more strongly than in the surface layer, while the opposite was true for bacterial growth (Table 2).

The ratio of bacterial biomass to phytoplankton biomass is regarded as a rough indicator of the trophic status of waters. The increase of the ratio during the observation period points towards the development of increasingly oligotrophic conditions at the station (Fig. 15). In detail, the ratio seemed to increase only until about 1998 and stabilized afterwards. Bacterial biomass was calculated from the number of bacteria multiplied by the average cell C-content over the 
Table 3. The matrix of correlations between environmental and microbial variables (Table 3a) and between chemical, microbial and environmental variables $($ Table $3 \mathrm{~b}$ ). Bold $=$ statistically significant, regular $=$ trend, statistically insignificant.

\begin{tabular}{|c|c|c|c|c|c|c|}
\hline & Salinity & Chlorophyll & Prim. prod. & Bact. number & Bact. growth & Bact. biomass \\
\hline Temperature & -0.477 & -0.122 & 0.248 & 0.427 & 0.576 & 0.306 \\
\hline$\left[{ }^{\circ} \mathrm{C}\right]$ & $<0.001$ & 0.0531 & $<0.001$ & $<0.001$ & $<0.001$ & $<0.001$ \\
\hline & 279 & 253 & 156 & 253 & 241 & 253 \\
\hline Salinity & & 0.187 & 0.0311 & -0.478 & -0.391 & -0.379 \\
\hline PSU & & $<0.001$ & 0.699 & $<0.001$ & $<0.001$ & $<0.001$ \\
\hline & & 254 & 157 & 253 & 241 & 253 \\
\hline Chlorophyll & & & 0.677 & -0.035 & $<0.001$ & -0.0212 \\
\hline$\left[\mu \mathrm{gL}^{-1}\right]$ & & & $\begin{array}{r}<0.001 \\
158\end{array}$ & $\begin{array}{r}0.559 \\
281\end{array}$ & $\begin{array}{r}0.957 \\
270\end{array}$ & $\begin{array}{r}0.724 \\
281\end{array}$ \\
\hline Prim. prod. & & & & 0.0761 & 0.0683 & 0.0209 \\
\hline$\left[\mathrm{mgCm}^{-3} \mathrm{~h}^{-1}\right]$ & & & & $\begin{array}{r}0.34 \\
159\end{array}$ & $\begin{array}{r}0.394 \\
158\end{array}$ & $\begin{array}{r}0.794 \\
159\end{array}$ \\
\hline Bacteria number & & & & & 0.609 & 0.695 \\
\hline$\left[\right.$ cells mL $\left.{ }^{-1}\right]$ & & & & & $\begin{array}{r}<0.001 \\
272\end{array}$ & $\begin{array}{r}<0.001 \\
285\end{array}$ \\
\hline $\begin{array}{l}\text { Bact. growth } \\
{\left[\mu g \mathrm{CL}^{-1} \mathrm{~d}^{-1}\right]}\end{array}$ & & & & & & $\begin{array}{r}0.495 \\
<0.001 \\
272\end{array}$ \\
\hline
\end{tabular}

Table 3. Continued.

\begin{tabular}{|c|c|c|c|c|c|c|c|}
\hline \multicolumn{8}{|c|}{$\begin{array}{l}\text { (b) Boknis Eck correlation matrix } \\
\text { Correlation coefficient, } r \\
P \text { value } \\
\text { Number of Samples }\end{array}$} \\
\hline & Oxygen & $\mathrm{pH}$ & Silicate & Phosphate & Ammonia & Nitrate & Chlorophyll \\
\hline Temperature & -0.757 & -0.103 & -0.213 & -0.199 & -0.236 & -0.561 & -0.122 \\
\hline \multirow[t]{2}{*}[{}^{\circ}\mathrm{C}]{} & $<0.001$ & 0.267 & $<0.001$ & $<0.001$ & $<0.001$ & $<0.001$ & 0.0531 \\
\hline & 273 & 118 & 276 & 277 & 275 & 276 & 253 \\
\hline Salinity & 0.0616 & -0.143 & 0.418 & 0.307 & 0.237 & 0.468 & 0.187 \\
\hline \multirow[t]{2}{*}{ [PSU] } & 0.31 & 0.123 & $<0.001$ & $<0.001$ & $<0.001$ & $<0.001$ & $<0.001$ \\
\hline & 274 & 118 & 277 & 278 & 276 & 277 & 254 \\
\hline Oxygen & & 0.437 & -0.203 & 0.141 & 0.0708 & 0.363 & 0.137 \\
\hline \multirow[t]{2}{*}[\mu\mathrm{M}]{} & & $<0.001$ & $<0.001$ & 0.0156 & 0.23 & $<0.001$ & 0.0261 \\
\hline & & 116 & 292 & 292 & 290 & 292 & 263 \\
\hline \multirow[t]{3}{*}{$\mathrm{pH}$} & & & -0.641 & -0.558 & -0.315 & -0.222 & -0.00412 \\
\hline & & & $<0.001$ & $<0.001$ & $<\mathbf{0 . 0 0 1}$ & 0.0155 & 0.967 \\
\hline & & & 118 & 118 & 117 & 118 & 105 \\
\hline Silicate & & & & 0.676 & 0.694 & 0.423 & 0.0271 \\
\hline \multirow[t]{2}{*}[\mu\mathrm{M}]{} & & & & $<0.001$ & $<0.001$ & $<0.001$ & 0.663 \\
\hline & & & & 295 & 293 & 295 & 261 \\
\hline Phosphate & & & & & 0.558 & 0.245 & 0.00196 \\
\hline \multirow{2}{*}[\mu\mathrm{M}]{} & & & & & $<0.001$ & $<0.001$ & 0.975 \\
\hline & & & & & 294 & 295 & 258 \\
\hline Ammonia & & & & & & 0.361 & -0.146 \\
\hline \multirow[t]{2}{*}[\mu\mathrm{M}]{} & & & & & & $<0.001$ & 0.0189 \\
\hline & & & & & & 293 & 260 \\
\hline & & & & & & & -0.0961 \\
\hline \multirow[t]{2}{*}[\mu\mathrm{M}]{} & & & & & & & 0.122 \\
\hline & & & & & & & 261 \\
\hline
\end{tabular}


entire period. Phytoplankton biomass was calculated from chlorophyll concentration multiplied by 50 .

\subsection{Regression analysis and correlation matrix}

Regression analysis (Table 2) of the surface water data set revealed seven significant $(P=0.05)$ and eleven insignificant relationships between time and variables. Thirteen of the variables showed a negative trend over the period of observation while five were positive. From the ten selected variables at depth, six showed significant regressions while four changed insignificantly.

The climate variables temperature and $\mathrm{pH}$ exhibited a slight temporal increase while salinity slightly decreased. Strongest declines of bacterial variables were recorded for bacterial biomass, bacterial growth (Thymidine uptake) and bacteria number, while the turnover rate of glucose strongly increased. Concerning the phytoplankton variables, primary production decreased more strongly than chlorophyll. From the chemical variables, nitrate declined most strongly, followed by phosphate, nitrite, silicate, ammonia and oxygen while $\mathrm{pH}$ slightly increased. The ratios between bacteria number (BN) or bacterial growth (Thy, Thymidine uptake) and chlorophyll (BN/Chl or Thy/Chl) showed positive trends, while the uptake of Thymidine per bacterium (Thy/BN) decreased.

The deviations (in variables from the corresponding interannual mean values over the $20 \mathrm{yr}$ period of observation are presented in Fig. 16. All microbial variables showed their strongest negative deviation from the interannual means during the years 1999 to 2002, roughly coinciding with low values of oxygen and salinity and relatively high temperatures (cf. Figs. 2, 4, 5). The strongest deviation was recorded for bacterial growth followed by chlorophyll and bacterial biomass. The ranges of deviation were between $\sim-70 \%$ and $\sim+100 \%$ for the different variables.

The correlation matrix (Table 3a, b) shows that all biological variables correlated significantly with temperature and salinity except chlorophyll (in case of temperature) and primary production (in case of salinity). Surprisingly, bacterial variables did not correlate with chlorophyll and primary production. This may be due to the time lag between the peaks of phytoplankton and bacteria (Findley et al., 1991; Hoppe et al., 2008), (Table 3a). However, on the base of the annual averages of these variables (omitting lag time effects), a significant correlation between chlorophyll and bacterial growth was observed and the correlation between chlorophyll and bacteria numbers improved (not shown). Remarkably, all nutrients correlated positively with each other while chlorophyll correlated positively only with salinity and oxygen and negatively with ammonia. As expected, all nutrients correlated positively with salinity and negatively with temperature (Table $3 \mathrm{~b}$ ). The correlations reflect mainly the similarity or dissimilarity of seasonal patterns of the compared variables. Long-term effects of change in climate and pol- icy are not well reflected because they are superimposed by the wide amplitudes of seasonal cycles of the measured variables.

\section{Discussion}

The environmental conditions at the time series station Boknis Eck are influenced by climate dependent hydrographical factors such as thermohaline stratification and vertical mixing, water exchange with the North Sea and the Baltic Sea current system. An additional factor derived from the aftereffects of changes in the political systems of the formerly socialistic southern and eastern Baltic Sea border states, which fell into the period of observation. Political change in 1989 and EU accession in 2004 caused a continuous improvement of environmental conditions in these states in the following years, e.g. by advanced industrial and agricultural management and waste water treatment (e.g. Farmer, 2008). However, improvements were mainly due to the reduction of nutrients originating from point sources, e.g. waste water purification plants, and to a lesser extent from diffuse depositions. Mediated by the current system, these remote factors influenced the conditions at the Boknis Eck station (Fig. 1). Local sources of eutrophication probably did not contribute considerably to the environmental development at the station because improvements of water management and river restoration had already started in the years before the investigation took place. Influences of the North Sea are considered to be relatively low because environmental changes in the North Sea (Wiltshire et al., 2010) were minor in comparison to those in the Baltic Sea. Nevertheless, despite recent progress, "the Baltic Sea is still dominated by factors of eutrophication and pollution introduced by the rivers and by the diffuse inputs of nutrients originating from agriculture and terrestrial organic matter" (HELCOM, 2009a). It was the question of this study as to which extent the time series station Boknis Eck, situated in the most western part of the Baltic Sea, was included into the general change of environmental conditions in the Baltic Sea. 
Salinity trends:

Sal. max.:

$y=-0.000052 x+20.36$

Sal. all data:

$y=-0.000064 x+16.86$

Sal. min. :

$y=0.000056 x+13.28$

Temperature trends:

Temp. max.:

$y=0.00024 x+16.82$

Temp. all data:

$y=0.00025 x+9.17$

Temp. min.:

$y=-0.00012 x+3.63$

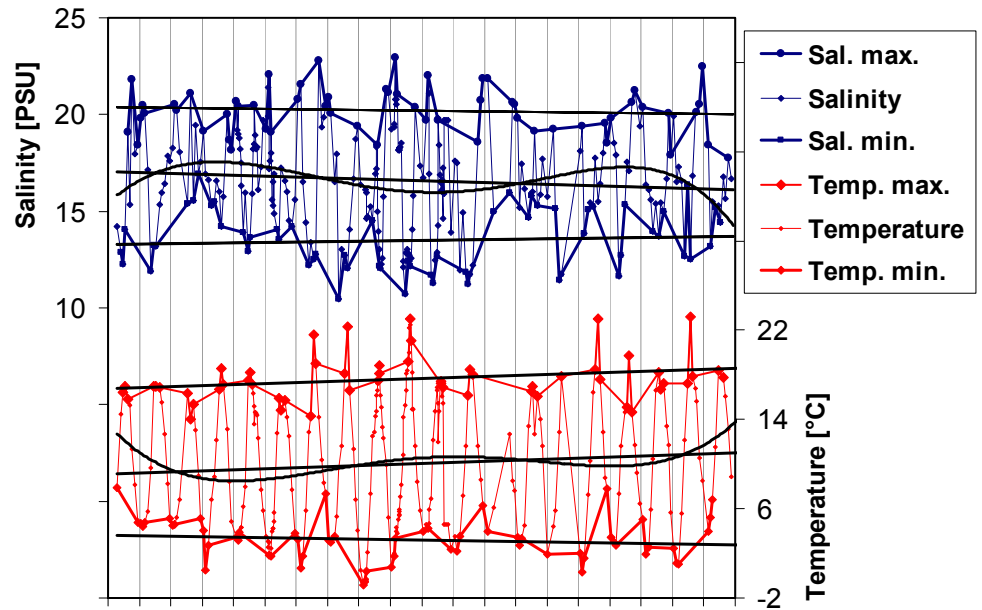

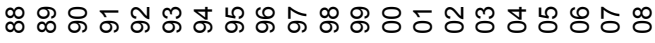

Year

Fig. 2. Changes of surface water salinity and temperature over $20 \mathrm{yr}$ at the time series station Boknis Eck. Trends (change per day) of all data (linear and polynomial) and of annual maximal and minimal values are shown.

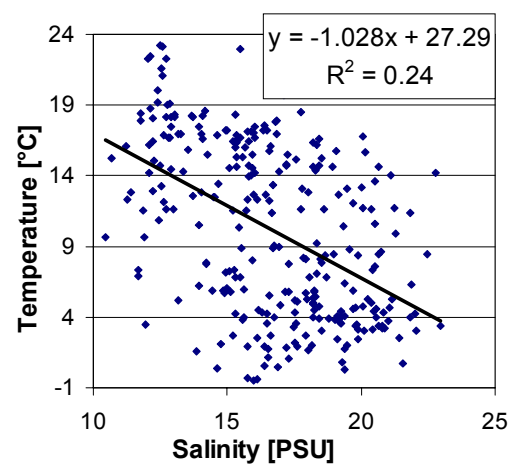

Fig. 3. Relationship between surface water temperature and salinity at Boknis Eck.

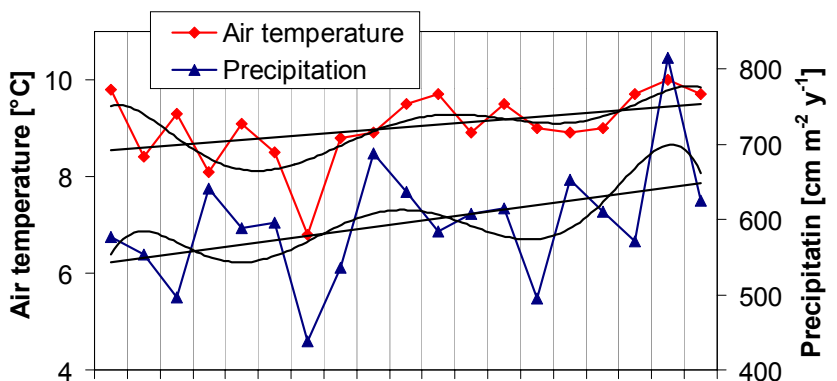

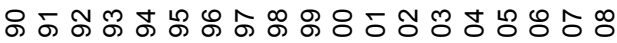

Year

Fig. 4. Developments of precipitation and air temperature over $18 \mathrm{yr}$ at the meteorological station Greifswald which is situated near the mouth of the river Oder, one of the biggest rivers in the southern Baltic Sea area. Linear and polynomial trends of the variables are shown. Equation of the linear trend of air temperature, change per yr: $y=0.053 x+8.50, R^{2}=0.159$; equation of the linear trend of precipitation, change per yr: $y=5.87 x+537, R^{2}=0.169$.

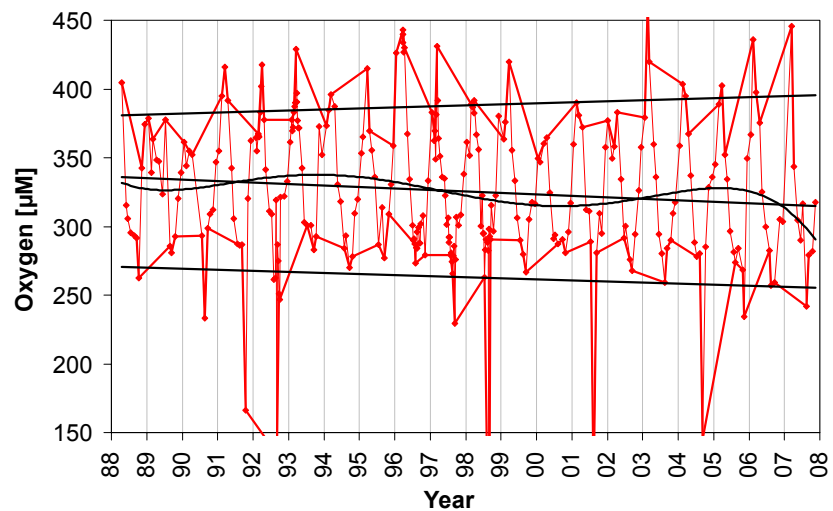

Fig. 5. Development of the surface water oxygen concentration over $20 \mathrm{yr}$ at Boknis Eck. Linear trends of annual maximal and minimal values and of all values (linear and polynomial) are shown. Equation of the linear trend of maximal values, change per day: $y=0.0019 x+381$; equation of the linear trend of all data on plot: $y=-0.0029 x+336$; equation of the linear trend of minimal values: $y=-0.0021 x+271$.
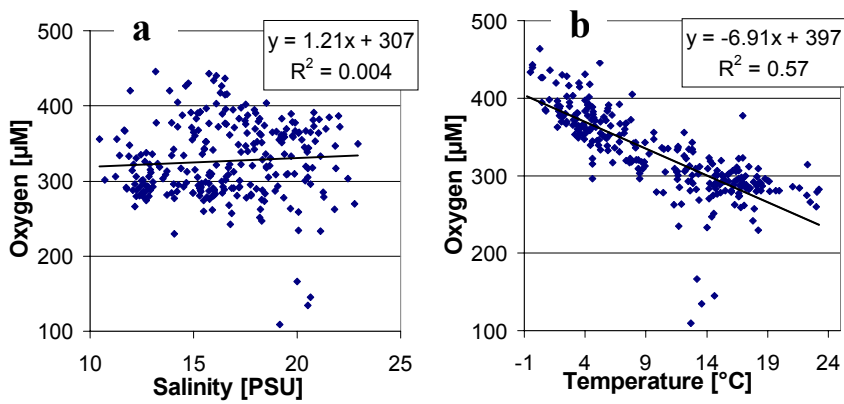

Fig. 6. Relationships between surface oxygen concentration and (a) salinity or (b) temperature at Boknis Eck. 

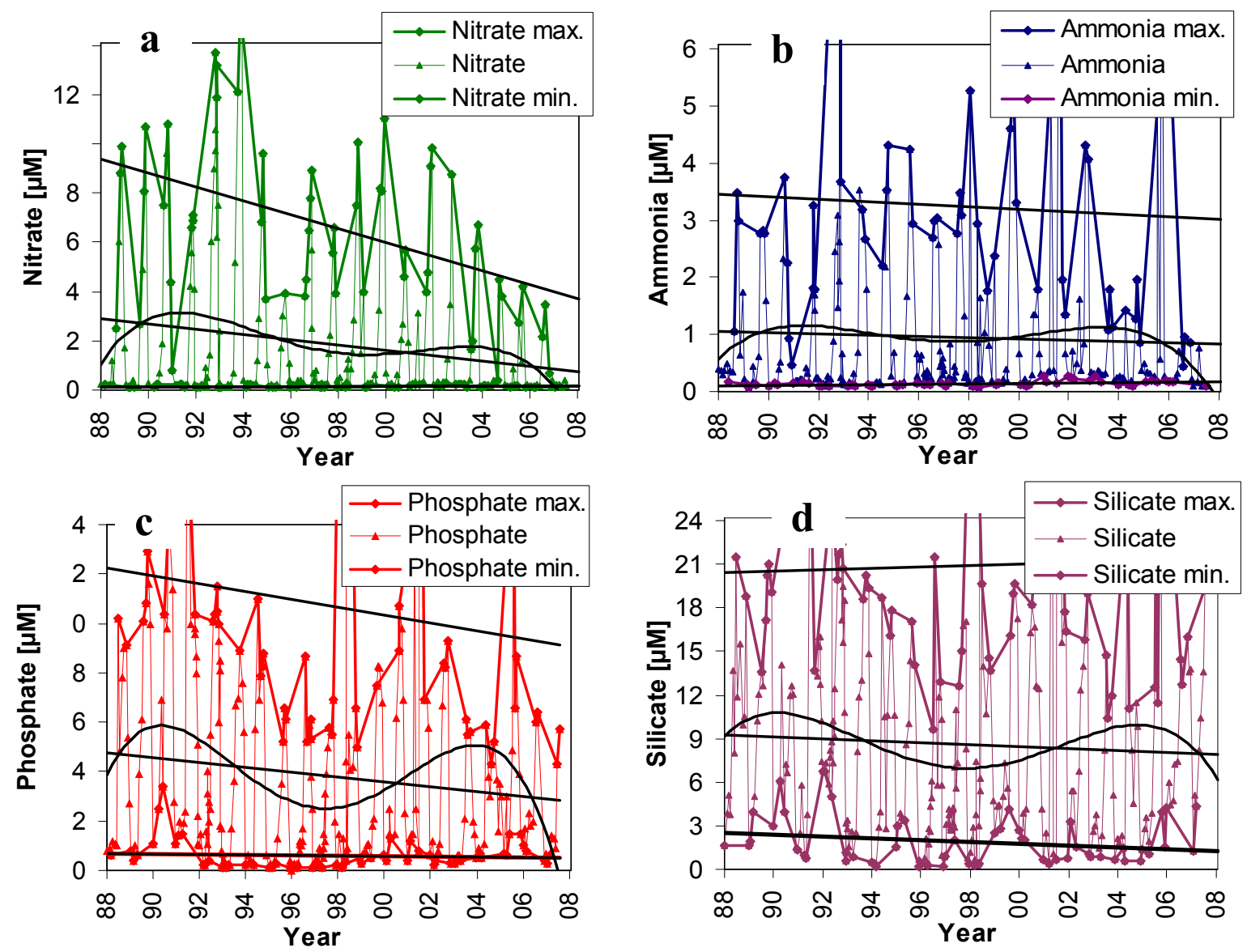

Fig. 7. The temporal developments of (a) nitrate, (b) ammonia, (c) phosphate and (d) silicate over 20 yr (linear and polynomial trends) at Boknis Eck and trends of annual maximal values of nutrients during winter and minimal values during summer. Equations of the trend lines (all data on plot) are shown in Table 2.
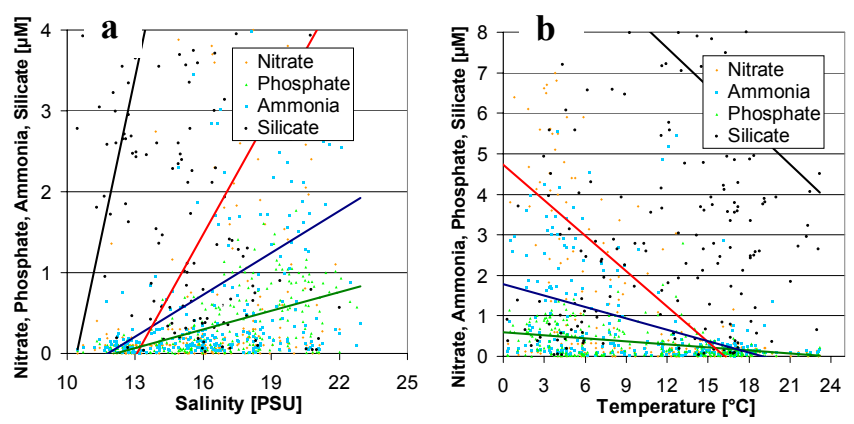

Fig. 8. Nitrate, ammonia, phosphate or silicate in relation to (a) salinity or (b) temperature over the past $20 \mathrm{yr}$ at Boknis Eck. The legends are arranged according to the depletion of nutrients at decreasing salinity or increasing temperature.

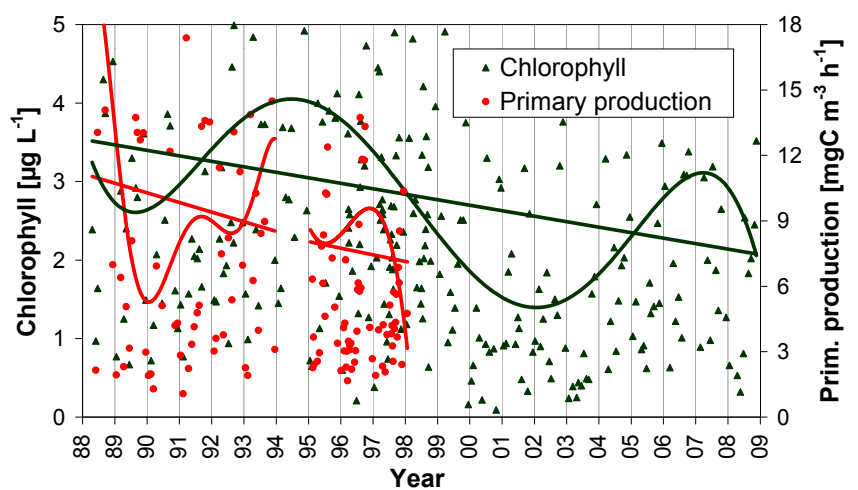

Fig. 9. Developments of chlorophyll $a$ and primary production over $20 \mathrm{yr}$ at the time series station Boknis Eck. The functions of linear trend lines are shown in Table 2. 


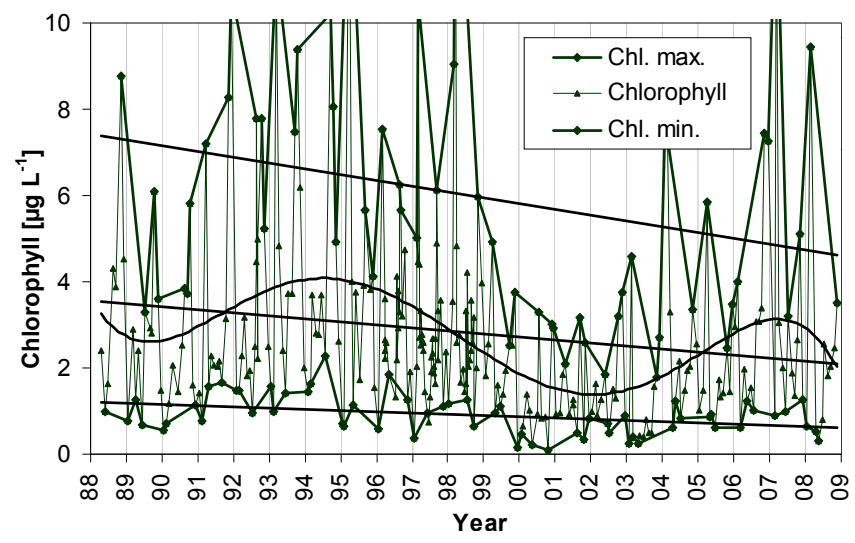

Fig. 10. Development of annual maxima and minima and of mean values of chlorophyll $a$ during $20 \mathrm{yr}$ at Boknis Eck. Equation of the linear trend of maximal values, change per day: $y=$ $-0.00037 x+7.38$; equation of the linear trend of all data on plot: $y=-0.00019 x+3.52$; equation of the linear trend of minimal values: $y=-0.000078 x+1.20$.

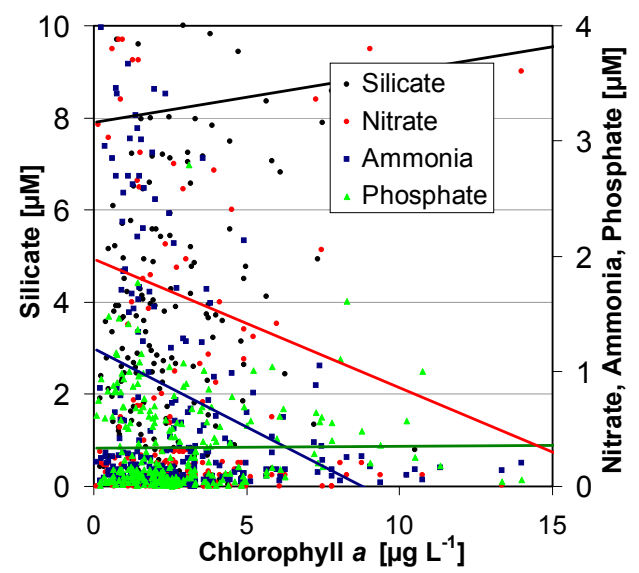

Fig. 11. Relationships between chlorophyll $a$ and nutrients at Boknis Eck. The legend is arranged according to the start positions of the trend lines.

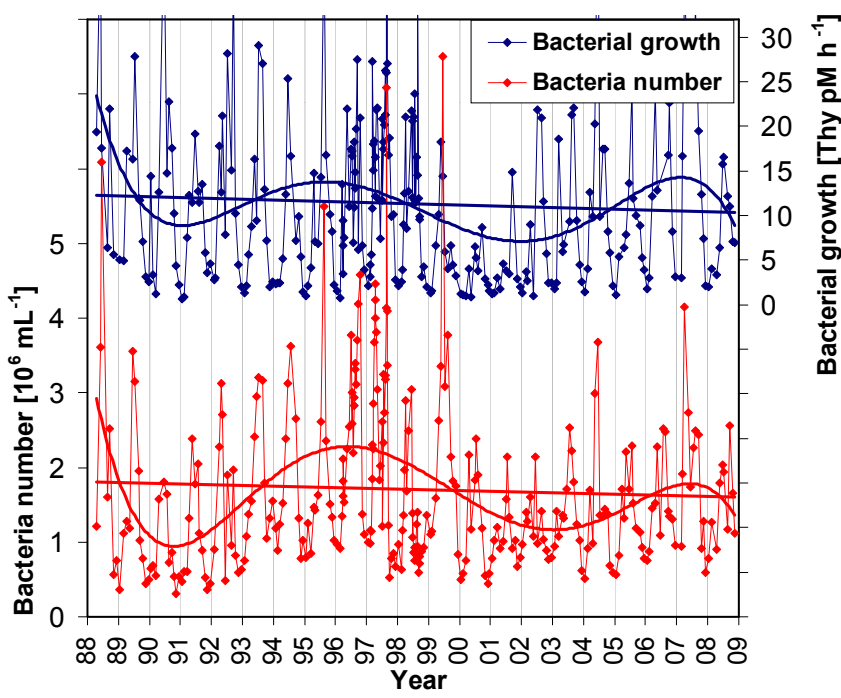

Fig. 12. Developments of bacteria numbers and bacterial growth over $20 \mathrm{yr}$ at Boknis Eck. Functions of linear trend lines are shown in Table 2.

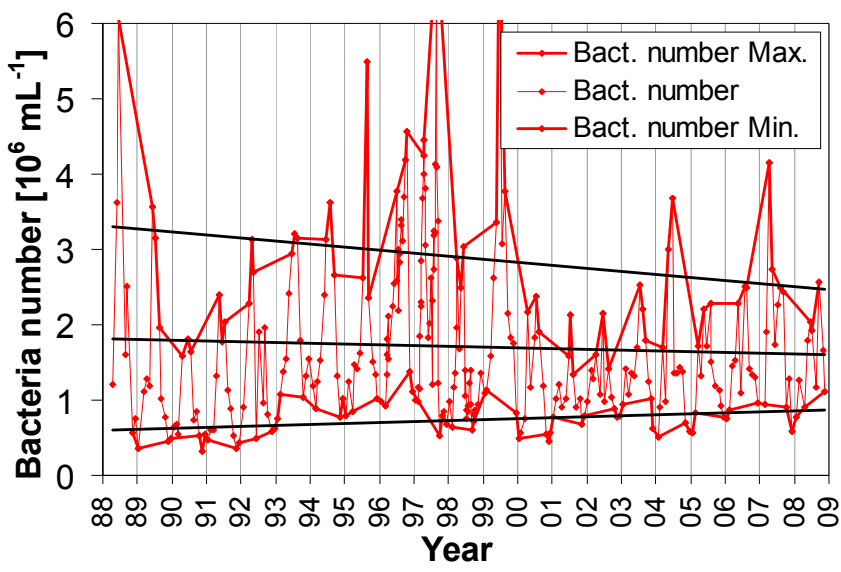

Fig. 13. Development of annual maxima and minima and of all values of bacteria abundance during $20 \mathrm{yr}$ at Boknis Eck. Equation of the linear trend of maximal values, change per day: $y=$ $-112.4 x+3.3 \cdot 10^{6}$; equation of the linear trend of all data on plot: $y=-27.9 x+1.8 \cdot 10^{6}$; equation of the linear trend of minimal values: $y=35.7 x+0.6 \cdot 10^{6}$. 

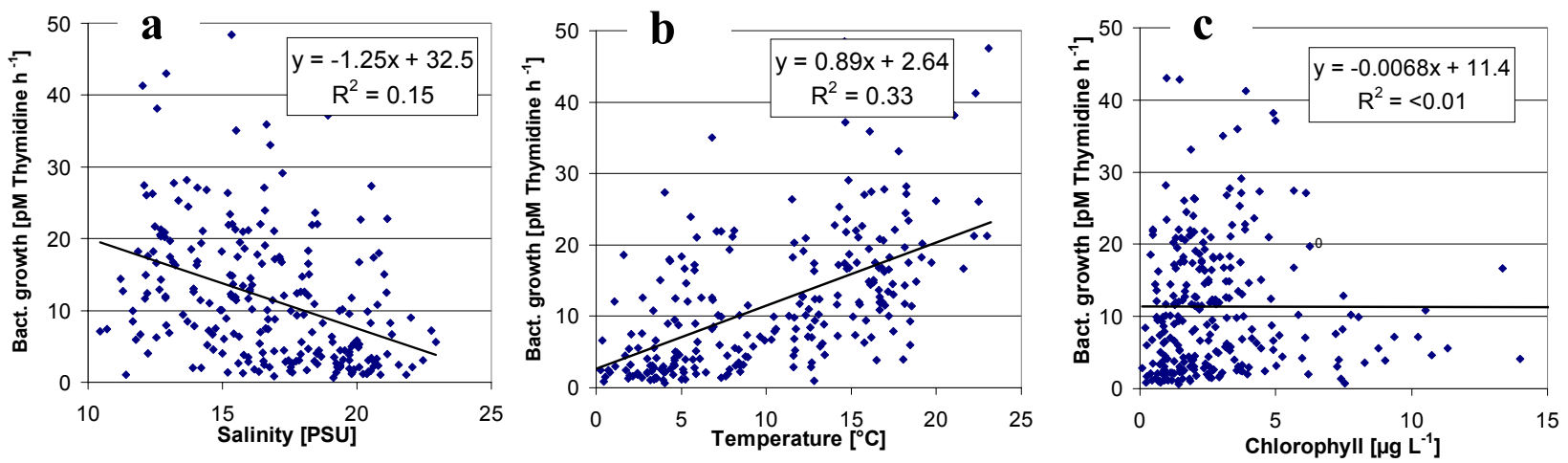

Fig. 14. Development of bacterial growth in relation to (a) salinity, (b) temperature and (c) chlorophyll during 20 yr at Boknis Eck.

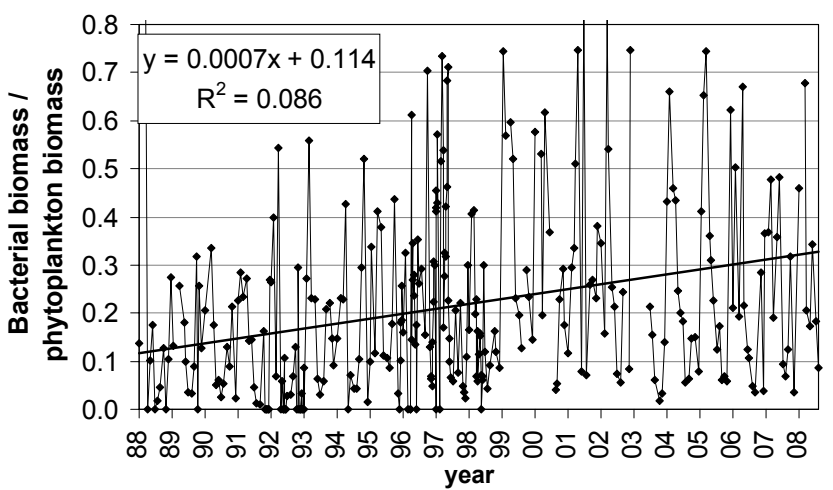

Fig. 15. Change of the relationship between bacterial and phytoplankton biomass during the period of observation.

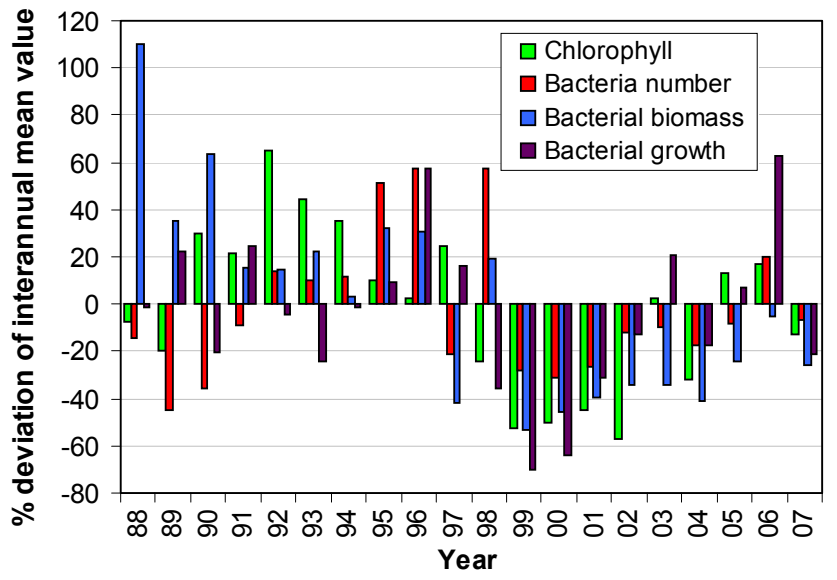

Fig. 16. Deviations of the annual means of chlorophyll and bacterial variables from the corresponding mean values $(=0 \%)$ over the 20 yr study period $(=0 \%)$.

\subsection{Changes in salinity and temperature}

Salinity at the time series station Boknis Eck is closely related to climate due to its dependence on (a) precipitation, regulating the fresh water inflow from the watersheds of the big rivers into the eastern and southern regions of the Baltic Sea (HELCOM, 2009b); (b) the wind-directed currents (Fig. 1), which are additionally influenced by the physical Coriolis force; (c) mixing of North Sea and Baltic Sea water in the Belt Sea area; (d) vertical water mixing and stagnation; and (e) the North Atlantic Oscillation (NOA). Starting with $16.86 \%$ in 1988 , salinity decreased slightly by $0.14 \%$ p.a. (insignificant) during the $20 \mathrm{yr}$ of observation (Fig. 2, Table 2; the figures are shown on separate pages at the start of the "Discussion". More information on the placement of the figures is provided in Sect. 2.6). The most probable two reasons for this decline may have been (a) increasing precipitation on land surrounding the Baltic Sea and/or (b) decreasing intensity of saline North Sea water intrusion into the Boknis Eck area.

Concerning factor (a): strong fresh water inflow into the southern Baltic Sea caused by extreme high waters in the Oder and Wisła rivers in 1997 coincided with a decrease in salinity and rise of temperature (polynomial regressions, Fig. 2) at the western Boknis Eck station. Extreme low water events in 2003 and 2008 were accompanied by low precipitation on land (Fig. 4) and relatively low temperature at the Boknis Eck station (concerning the year 2003, Fig. 2). Hot and dry summers in 1992 and 2003 were reflected by low precipitation (Fig. 4) and relatively high salinity at the Boknis Eck station (Fig. 2). Over the period of investigation, the annual values of precipitation on land surrounding the southern Baltic Sea (represented by an example from the estuary mouth of the Oder river, Fig. 4) showed a significantly negative correlation with salinity at the western Boknis Eck station: $y=-1.88 x+80.45, R=-0.186, P=0.0095$, $N=19$. This finding suggests a strong impact of precipitation in the catchment area of the big streams on salinity of the Baltic Sea proper, expanding to the Boknis Eck station 
via the westerly directed currents. The correlation between the monthly data of air temperature and precipitation near the Oder estuary was: $y=0.0763 x+5.2404, R=0.3321$, $P=0.005, N=214$. This finding suggests that air temperature and precipitation are positively related to each other in the Baltic Sea region.

Concerning factor (b), major events of North Sea water intrusion into the deep basins of the Baltic Sea occurred in the years 1993, 1997 and 2002. The impact of these events on surface water salinity was not recognizable at the station because it takes several years until saline North Sea water in the deep layer of the Baltic Sea mixes with surface water.

Results from other studies support our observations. In the eastern Baltic proper a decrease of salinity by $\sim 1$ PSU since the 80th, accompanied by a corresponding increase in river runoff, was reported by Vuorinen et al. (1998) and Gustafsson (2001). Another reason for the recorded salinity decrease may be that over a long stagnation period since 2004, no strong input of North Sea water into the Baltic Sea occurred (Feistel et al., 2010). In contrast to the development in the Baltic Sea, salinity increased at the "Helgoland roads" time series station in the North Sea (Wiltshire et al., 2010). This may be due to the different hydrographical characteristics of the two seas: in the semi-enclosed Baltic Sea (increasing) precipitation has a stronger effect on salinity than in the open North Sea.

Surface water temperature at Boknis Eck depends on (a) the season, (b) water stratification and vertical mixing, (c) the Baltic Sea current system and (d) climate warming. Temperature is regarded as an important factor for the regulation of bacterial activity but to a lesser extent for phytoplankton growth.

Surface water temperature at Boknis Eck increased by $0.09^{\circ} \mathrm{C}$ p.a. during the $20 \mathrm{yr}$ of observation. The rise of temperature during summer counterbalanced the slight decrease of temperature during winter, resulting in an overall increase of the annual water temperature (Fig. 2, Table 2). The increase of water temperature during summer may have been supported by a stabilization of the thermohaline stratification due to climate warming. Furthermore, surface water temperature at Boknis Eck was probably co-determined by the increasing dominance of Baltic Sea water (cf. above), which is warmer than North Sea water in summer and colder in winter (North Sea in summer $16-19^{\circ} \mathrm{C}$, Baltic Sea $17-23^{\circ} \mathrm{C}$, North Sea in winter $4-7^{\circ} \mathrm{C}$, Baltic Sea $0-3^{\circ} \mathrm{C}$, respectively).

Interestingly, the annual ranges of temperature were narrow during the early 1990s and 2000s and wide during the mid- to late 1990s (Fig. 2), corresponding to even more pronounced narrow or wide annual ranges of salinity, respectively. From the polynomial trend lines, (Fig. 2) it can be derived that low salinities during summer corresponded to increasing summer temperatures, while high salinities during summer were reflected by decreasing temperatures. The inverse relationships between salinity and temperature can be regarded as an indicator of changes in the relative influence of Baltic and North Sea water at the station.

The observed increase of surface water temperature at Boknis Eck is in accordance with other investigations in different parts of the Baltic Sea (e.g. Lehmann et al., 2011). However, in contrast to our data, strongest increases were recorded during winter and spring (e.g. HELCOM, 2009a). Our study suggests strong elevation of surface water temperature during summer (Fig. 2) while the temperatures in April varied only little around $6{ }^{\circ} \mathrm{C}$ and showed no clear tendency towards an increase earlier in the year (not shown). This discepancy is probably due to the wide west to east extension of the Baltic Sea covering different climate regimes. Temperature increase at Boknis Eck was stronger than that recorded at the time series station "Helgoland roads" in the North Sea with $0.04{ }^{\circ} \mathrm{C}$ per year (significant, derived from $45 \mathrm{yr}$ of monitoring) (Wiltshire et al. 2010). However, a close look at the Fig. 1 of their publication shows that during the recent $20 \mathrm{yr}$, the increase was probably steeper than the average increase of temperature during the entire period.

According to HELCOM (2007) the warming trend for the entire globe was about $0.05^{\circ} \mathrm{C}$ per decade from 1861 to 2000 , while the trend for the Baltic Sea basin was larger with $0.08{ }^{\circ} \mathrm{C}$ per decade. Our values suggest a much stronger increase of surface water temperature in the western part of the Baltic Sea. Stronger surface temperature increase at Boknis Eck may be inherent with specific local factors such as the low water depth, allowing mixing of relatively warm North Sea water with cold surface water during winter and the location of the station in the most western part of the Baltic Sea, which is characterized by mild winters in contrast to cold winters in the eastern part.

\subsection{Changes in oxygen content and $\mathrm{pH}$}

The surface oxygen concentration at the Boknis Eck station is influenced by many factors: (a) gas exchange with the atmosphere, (b) the intrusion of oxygenated North Sea water into the deep trenches, (c) water exchange with hypoxic deep water during periods of vertical mixing, (d) duration of thermohaline stratification periods, (e) oxygen regeneration by photosynthesis, (f) oxygen consumption by heterotrophs, and (g) bacterial nitrification (Rheinheimer, 1967) and methane oxidation (Schmaljohann, 1996; Bange et al., 2010; Naqvi et al., 2010). The great variety of factors influencing the oxygen concentration at the station does not allow a clear decision about the dominant regulating factors. Most likely the long stagnation period without remarkable events of oxygenated North Sea water intrusion played an important role in the decline of oxygen in the Baltic Sea.

The average concentration of oxygen at Boknis Eck over the whole period was $326 \mu \mathrm{M}$ (Table 1). The oxygen concentration decreased by $1.059 \mu \mathrm{M}$ p.a., corresponding to a decline of the initial concentration by $0.32 \%$ p.a. (Table 2). While the maximal oxygen concentrations, which 
were reached during winter/early spring, seemed to increase over the $20 \mathrm{yr}$, a decrease was observed for the minimal concentrations during summer, leading finally to an overall decline of the oxygen content during the period of observation (Fig. 5). Even if the values of extremely low surface oxygen concentrations during late summer (Fig. 6b) were omitted, the general trend remained negative. When oxygen dropped down to $150 \mu \mathrm{M}$ or below in surface water $(\sim 5$ times during the period, due to vertical mixing with hypoxic water from the deep in late summer/fall), this was combined with an increase in salinity, temperature, silicate, ammonia, phosphate and thymidine uptake (bacterial growth) and a decrease in $\mathrm{pH}$, nitrate, bacteria number and biomass (Table 1). Similar observations were made in anoxic/hypoxic bottom water, with the exception that bacteria number and biomass increased at these conditions (Table 1). Generally, a decline of the oxygen content in the western Baltic Sea had already been reported earlier by Weigelt (1990, 1991), Babenerd (1991), Hansen et al. (1999) and Nausch et al. (2011b). Thus our observations demonstrate a continuation of this trend.

The increase of $\mathrm{pH}$ (Table 2) at the station from 8.07 to $\sim 8.37$ (within ca. $10 \mathrm{yr}$ ) contrasts with the recently observed trend of acidification in the sea (e.g. Turley et al., 2006). However, acidification seems to be a relatively new phenomenon. Until at least 1988, a rise in $\mathrm{pH}$ values of 0.01 to 0.03 units p.a. was observed in many regions of the Baltic Sea (HELCOM, 1990). This was attributed to positive effects of eutrophication on $\mathrm{CO}_{2}$ consumption of phytoplankton, counteracting anthropogenic atmospheric $\mathrm{CO}_{2}$ increase. Theoretically it could be expected that reduced eutrophication during recent years (cf. below) might have favoured the effect of atmospheric $\mathrm{CO}_{2}$ increase on marine $\mathrm{pH}$, leading to acidification. In our study $\mathrm{pH}$ was measured only until 1998. Change of $\mathrm{pH}$ in a buffered system like the sea is a very slow process, thus it could be that we did not become aware of acidification in Boknis Eck waters during the last years when $\mathrm{pH}$ was not measured. Furthermore, $\mathrm{pH}$ of the Baltic Sea is influenced by the $\mathrm{pH}$ of the big rivers and depends thus also on precipitation. According to Schneider (2011) the mean pH in the central Baltic Sea will decrease from currently 8.07 to 7.91 during the next $100 \mathrm{yr}$ due to the rise in atmospheric $\mathrm{CO}_{2}$. This could not be verified by our study but in the long run, acidification may dominate if the present positive trend of $\mathrm{CO}_{2}$ concentrations in the air and less consumption of $\mathrm{CO}_{2}$ by decreasing phytoplankton (c.f. below) continue.

\subsection{Changes in macro-nutrients}

Nutrients are key factors for the development of phytoplankton growth, which represents in turn the nutritional base of bacteria. The observed decreases of the nutrients (Fig. 7a-d, Table 2) ammonia, nitrate, phosphate and silicate are caused by factors like (a) improved sewage treatment, (b) less input from rivers and land (Voss et al., 2011), (c) change in the mixing of North Sea with Baltic Sea water, (d) change in precipitation (climate effect) and (e) vertical mixing and extension of anoxic zones in the deep. Due to the current system, reduction of the nutrient load in the southern and eastern parts of the Baltic Sea may have influenced the nutrient status at western Boknis Eck station. However, in the case of phosphate the decline could have been even stronger if it hadn't been counteracted by the phosphate output from anoxic sediments during vertical mixing periods (Table 1). The importance of this source increases relative to the reduction of the phosphate concentration in surface water by effects of improved waste water management. In contrast, concerning nitrate, the decline caused by the after-effects of political change may have been supported by processes of denitrification in the deep hypoxic zones (Kähler, 1991) and decreasing airborne N-supplies. Surprisingly, in contrast to other regions of the Baltic Sea (e.g. Nausch et al., 2011a), nitrate decreased more strongly than phosphate at Boknis Eck (Table 2). We attribute this to very strong recycling of phosphate from the anoxic zones at the shallow station (Table 1). In the seasonal cycle all nutrients declined significantly with rising temperature and increased with salinity, reflecting the combined effects of season, climate warming and hydrographical conditions on the nutrient regime at the station (Fig. 8a, b, Table 3b).

Negative trends for nitrate and phosphate were reported also for the outer Kiel Fjord, adjacent to the Boknis Eck station, by Nausch et al. (2011a). In addition, these authors assessed a reduction of the input of phosphate by $61 \%$ (2004-2008 compared to 1986-1990) for important German river discharges. This was attributed mainly to strong reductions of emissions from point sources (water purification plants). At the same time nitrate inputs from diffuse sources were reduced by only $13 \%$, whereby half of the decrease was due to lower runoff (Nausch et al., 2011a). These results supported those of Dorendorf (2007), who observed a decrease of nutrients in the Oder estuary already since the beginning of the 90th on the base of long-term studies. Mediated by the circulation of surface currents in the Baltic Sea, the reported strong reductions of nutrient concentrations influenced the nutrient regime in the most western Boknis Eck station. More detailed information on the development of the diverse nutrients in the southern and eastern Baltic Sea area before and after the start of our time series in 1988 is presented in the figures and tables of the Supplement.

In contrast to nitrate and the other nutrients, ammonia concentrations at Boknis Eck (average $0.98 \mu \mathrm{M}$, Table 1) declined only slightly by $\sim 0.0055 \mu \mathrm{M}$ p.a., corresponding to $0.59 \%$ p.a. (Fig. 7b, Table 2). This may be surprising because ammonia is regarded as an indicator of untreated sewage, which was drastically reduced during the recent years. Nevertheless, change in the ammonia concentration was low probably due to the observed oxygen decline and the intrusion of ammonia-rich deep water (Table 1) into the surface layer during periods of vertical mixing. Intrusion of hypoxic deep water into the surface layer during periods of vertical 
mixing may have been responsible for silicate increase in late summer (Fig. 7d). According to Wasmund et al. (2011b), a slight increase in the concentration of silicate during fall was also recorded in the adjacent Mecklenburg Bight. Ammonia decrease at Boknis Eck is in accord with the decline of ammonia measured at the Helgoland roads station in the North Sea (Wiltshire et al., 2010). However, the annual decrease of roughly $2.5 \%$ in the North Sea during the $20 \mathrm{yr}$ from 1982 to 2002 was much steeper than that at Boknis Eck $(\sim 0.6 \%$ p.a.). Again it seems that the regeneration of nutrients, in this case ammonia, from the shallow anoxic bottom water (which does not play a role in the North Sea) counteracted the progress in waste water management in the Baltic Sea border states.

\subsection{Developing of phytoplankton}

Chlorophyll $a$ concentration and potential primary production at the time series station depend on nutrients, light, indirectly on salinity (water exchange between the North Sea and the Baltic Sea) and grazing. As a consequence of the negative trends of all key-nutrients (cf. above), chlorophyll declined significantly by $1.97 \%$ p.a., corresponding to $0.07 \mu \mathrm{gL}^{-1}$ p.a. (the average chlorophyll concentration was $2.81 \mu \mathrm{gL}^{-1}$ ) during the $20 \mathrm{yr}$ period of observation (Fig. 9, Tables 1, 2). Decrease of chlorophyll was stronger for the maximal spring bloom values than for the minimal values during winter (Fig. 10), corresponding inversely to the patterns of nutrients (except silicate). Chlorophyll was not directly affected by salinity but more likely by the different loads of nutrients and algae transported by currents with different salinities. Noticeably, primary production (incomplete series) followed the negative trend of chlorophyll with a slightly stronger decrease, indicating possibly changes in species composition and grazing. Concerning light, the development of this factor was not measured at the station. Brightening was observed during the period of observation in the moderate climate zone (Wild et al., 2005) and might have triggered phytoplankton growth. Nevertheless, chlorophyll and C-fixation in the surface declined, mainly due to limitation by nutrients.

Phytoplankton community composition was not included in this study. The long-term development of phytoplankton biomass and species distribution in the Kiel Bight has been reviewed by Smetacek (1985) and Wasmund et al. (2008). According to the latter, "diatomophyceae and dinophyceae still represent the dominant groups, accounting for $\sim 90 \%$ of total phytoplankton biomass on an annual average. In the spring bloom peak diatomophyceae represented at least $80 \%$ of carbon biomass at the beginning of the 20th century".

It was our question as to what extent and temporal scale the improvement of water quality in the southern and eastern Baltic Sea regions (after political change) was exported to the western time series station Boknis Eck by the predominant westward currents along the northern coastline. As documented by Wasmund et al. (2006) and Wasmund et al. (2011a, time series from 1978 to 2008), nutrient decline led to a reduction of chlorophyll during spring in the Mecklenburg Bight, adjacent to the Kiel Bight. This reduction had already started before the year of political change. Nevertheless, a close look at Fig. 3 of Wasmund et al. (2011a) exhibits a minor trend break in the chlorophyll values after 1989. Also in the Pomeranian Bight, east of the Mecklenburg Bight, the spring bloom chlorophyll values decreased and a trend break occurred in the years around 1989. In the regions directly adjacent to Boknis Eck, the Kiel Bight and the Lübeck Bight, no significant trends of the spring bloom values of chlorophyll could be detected by Wasmund et al. (2011a) during the time when our investigation took place. This can probably be attributed to the different sampling locations; while our Boknis Eck station was situated very close to the coast and rich in chlorophyll, their stations were located remotely from the coast and contained relatively little chlorophyll. Generally, trends in chlorophyll concentration can be assessed easier and more reliably at high concentrations than at low ones.

This discussion demonstrates the complexity of the environmental and hydrological conditions in the Baltic Sea, leading to an unsteady temporal and spatial distribution of improvements in water quality over the different Baltic Sea basins. Nevertheless it turned out that the negative trend of chlorophyll in the southern and eastern Baltic Sea areas after political change was well reflected by the development of chlorophyll at the western Boknis Eck monitoring station.

The favoured N-nutrient by phytoplankton seems to be ammonia, which depleted first at increasing chlorophyll, followed by nitrate (Fig. 11, Table 3b). Increasing chlorophyll did not lead to depletion of phosphate and silicate. However, considering the correlation between nutrients and temperature it seems that nitrate vanished first, followed by ammonia and phosphate (Fig. 8b). This may be due to the fast generation of ammonia at elevated temperatures and reduced oxygen concentration (Fig. 5) during late summer.

\subsection{Developing of bacterial variables}

Bacteria represent the first and most important heterotrophic level in the marine food web. Bacterial variables, bacteria number (BN), bacterial growth (measured by Thymidine uptake) and the related parameters (bacterial biomass, ratios between bacteria and other variables) react mainly on organic matter supply by phytoplankton (degradation of exudates and phytoplankton biomass after the spring bloom), on external organic matter input by rivers and from land, on temperature and grazing.

Bacteria numbers and bacterial growth declined by $0.56 \%$ p.a. and $0.77 \%$ p.a., respectively, during the period of observation (Fig. 12, Table 2), following clearly the negative trends of nutrients and phytoplankton variables. Growth of individual bacteria (Thy/BN, Table 2) decreased more strongly than chlorophyll, indicating deficits in autochthonous substrate supply of bacteria. On the other hand, 
the number of bacteria per unit of chlorophyll (BN/Chl) increased considerably during the period of observation by $4.95 \%$ p.a. (Table 2). This may be related to different factors such as increasing dependency of bacteria from allochthonous sources of organic matter (e.g. by river runoff) or reduced grazing pressure on bacteria. The strongly negative trends of the maximal values of bacteria numbers (Fig. 13) and bacterial growth (not shown) after the phytoplankton spring bloom reflect clearly the recorded decline of chlorophyll during the spring bloom.

Unfortunately there are no long-term records of bacteria in the surface layer of the Baltic Sea available for comparison with our Boknis Eck data. However, there exists a time series from 1994 to 2010 of bacterial growth below the pycnocline in the Bothnian Bay, using the same method as we did (Wikner, 2011). Decline of bacterial growth was $2.8 \%$ p.a. averaged over the whole Gulf of Bothnia. For the period from 2000 to 2010 reduction even accounted for $4.8 \%$ p.a. Bacterial growth rate decreased from $44 \mathrm{nMCd}^{-1}$ during 1994-2010 to $34 \mathrm{nMCd}^{-1}$, if only the period between the years 2000-2010 was considered. The decline was explained by a poorer nutrient status of the bacteria. Though not directly comparable with our data set from surface water, these data document together with ours $(0.77 \%$ p.a. reduction of bacterial growth, Table 2) a general trend of declining bacterial activities in the Baltic Sea. This does not mean a negative development as long as the relationship between bacteria and phytoplankton is not negatively affected (cf. Fig. 15).

Derived from correlation analysis there was a very strong negative effect of salinity on bacteria number and bacterial growth (c.f. Table 3a, Fig. 14a). However, this statistical correlation cannot directly be attributed to the effect of salinity on bacteria because the halo-tolerant bacteria prevailing in the Baltic Sea are well adapted to a wide range of salinity. It is more likely a seasonal effect, because high salinity during winter is usually combined with low substrate availability. Concerning the impact of temperature on bacterial variables an increase of bacteria numbers per $\mathrm{mL}(\mathrm{BN})$ of $\sim 80800$ per $1{ }^{\circ} \mathrm{C}$ warming was calculated from the data at Boknis Eck $\left(y=80800 x+925000 ; R^{2}=0.18\right.$, corresponding patterns of bacterial growth are presented on Fig. 14b). During the same period of time an increase of bacterial numbers per $\mathrm{mL}$ of only 61000 per $1{ }^{\circ} \mathrm{C}$ warming was recorded at the Helgoland roads time series station (Gerdts et al., 2004). In this case it has to be considered that bacterial numbers at Boknis Eck were generally much higher than those at the North Sea station and that the nutritional status of bacteria in the coastal Boknis Eck station was certainly better than at the remote Helgoland roads station.

The relationship between bacteria and phytoplankton at Boknis Eck increased slightly during the period of observation (Fig. 15, Table 2). Generally, it is assumed that an increase of this relationship suggests a change of the ecosystem towards more oligotrophic and heterotrophic conditions (e.g. Gasol et al., 1997). We conclude from our observations that the Baltic Sea is far from being oligotrophic. However, our results suggest a positive trend towards this condition during the last $20 \mathrm{yr}$ which can mainly be attributed to the after-effects of political changes. Continuous efforts of the western and northern border states may have supported this development.

Interestingly, nearly all variables showed a strong decline around the beginning of the new century and increased slightly afterwards (concerning microbial variables, c.f. Fig. 16). This may be related to the long stagnation period before North Sea water intrusion occurred in the year 2003. On the other hand, this decline happened about $10 \mathrm{yr}$ after political change and may thus indicate how long it lasted until effects of environmental improvement penetrated the outer boundaries of the Baltic Sea. A recovery of variables after the start of the new century was also observed by other studies (e.g. Nausch et al., 2011a; Wasmund et al., 2011a) and may probably be a signal of increasing river discharge due to precipitation (Helcom, 2009a, b) and/or the recovery of agriculture in the border states after political change, leading to an increase in the use of fertilizers after a period of stagnation.

\section{Conclusions}

Change in the political system of several Baltic Sea border states gave us the rare chance to investigate the combined effects of economy and climate on environmental and microbial variables at the time series station Boknis Eck during the post-socialistic era from 1988 to 2007.

The results of our long-term study at Boknis Eck indicate changes of the values of climatic, chemical and microbial variables within the relatively short period of $20 \mathrm{yr}$ observation. Most of the variables (13 out of 18) exhibited negative trends while those of temperature, glucose turnover rate and the ratios between bacterial variables and chlorophyll were positive. Especially the ecological key parameters nitrate, phosphate, chlorophyll as well as bacterial biomass decreased significantly (Table 2). These findings can be regarded as a strong signal for positive changes in the Baltic Sea ecosystem caused by climatic and economical developments. In this place it should be mentioned that climate change itself provides feedback at least partly on political developments.

The correlation of precipitation in the southern Baltic Sea area with salinity at the western Boknis Eck station suggests indirectly that the improvement of water quality in the southern area (where the big rivers enter the sea) influenced the conditions at Boknis Eck via the predominant westward currents.

The results obtained from the station Boknis Eck were generally in agreement with former statements, e.g. HELCOM (2006), with some differences due to special conditions at the shallow Boknis Eck station, which is situated at the most western border of the Baltic Sea. 
Decline of the key nutrients caused pronounced decreases of phytoplankton and, in turn, bacterial variables. A strong decrease of the values occurred especially from 1999 to 2003, about $10 \mathrm{yr}$ after political change, demonstrating the long-time lag required for spreading improved environmental conditions all over the Baltic Sea proper. This development was probably reinforced by special hydrographical conditions during the time of investigation.

The after-effects of political change were supported or counteracted by the environmental effects of climate change. Re-mobilization of stored products from former periods of eutrophication and pollution in the sediment counteracted recent efforts of water quality improvement.

Comparison with data from other regions of the Baltic Sea showed that the observations from Boknis Eck represent general trends and confirm influences from remote sources of eutrophication.

The combined efforts of the border states improved the environmental status of the Baltic Sea. Effects of political/economical change overmatched those of climate change. This statement is supported by a comparison of the developments in the North Sea and the Baltic Sea, both being situated in the moderate climate zone. Due to the additional effects of political change in the Baltic Sea improvement of environmental conditions was stronger than in the North Sea.

In the Supplement (Tables 4 and 5 and Figs. 17 to 21) we show by examples from the literature that the positive development of the environmental conditions in the Baltic Sea started (or proceeded) with the improvement of conditions on landside after political change.

\section{Supplementary material related to this article is available online at: http://www.biogeosciences.net/10/ 4529/2013/bg-10-4529-2013-supplement.pdf.}

Acknowledgements. The authors thank the captain and crew of RS Littorina for successful collaboration on about 200 cruises in all weather. Petra Krischker and Peter Fritsche measured primary production, many thanks to them. We thank WetterKontor GmbH, http://www.wetterkontor.de/ and Deutscher Wetterdienst, http://www.dwd.de/ for the permission to make use of their data of temperature and precipitation. We also thank Springer-Verlag (Heidelberg) and HELCOM for the permission to use figures from their journals in the discussion and supplement of our paper. Last but not least we thank the two reviewers for their critical but constructive comments on our paper. This study was partly granted by funds of the former German Ministry of Research and Technology (BMFT).

Edited by: H. Bange

The service charges for this open access publication have been covered by a Research Centre of the Helmholtz Association.

\section{References}

Babenerd, B.: Increasing oxygen deficiency in Kiel Bay (Western Baltic), Meeresforschung, 33, 121-140, 1991.

Bange, H. W.: Boknis eck time series station, LOICZ inprint, 3, 12 $14,2010$.

Bange, H. W., Bergmann, K., Hansen, H. P., Kock, A., Koppe, R., Malien, F., and Ostrau, C.: Dissolved methane during hypoxic events at the Boknis Eck Time Series Station (Eckernförde Bay, SW Baltic Sea), Biogeosciences, 7, 279-1284, 2010, http://www.biogeosciences.net/7/279/2010/.

Bange, H. W., Hansen, H. P., Malien, F., Laß, K., Karstensen, J., Petereit, C., Friedrichs, G., and Dale, A.: Boknis Eck Time Series Station (SW Baltic Sea): measurements from 1957 to 2010, LOICZ inprint, online, 1, 16-22, 2011.

Dorendorf, S.: Zeitliche Dynamik der Nährstofffrachten der Oder im Hinblick auf Konsequenzen für das Stettiner Haff, IKZMOder Berichte, 38, 1-90, 2007.

Farmer, A.: The Role of the EU Nitrates, Water Framework and Proposed Marine Strategy Directives in Reducing Nutrient Pollution from Agriculture to the Baltic Sea, BalticSea2020 Report, 1-47, 2008.

Feistel, R., Nausch, G., and Mohrholz, V.: Water Exchange Between the Baltic Sea and the North Sea, and Conditions in the Deep Basins, HELCOM Indicator Fact Sheets 2010 , available at: http://www.helcom.fi/BSAP_assessment/ifs/archive/ ifs2010/en_GB/WaterExchange/, 2010.

Findley, S., Pace, M. L., Lints, D., Cole, J. J., Caraco, N. F., and Peierls, B., Weak coupling of bacterial and algal production in a heterotrophic ecosystem: the Hudson River Estuary, Limnol. Oceanogr., 36, 268-278, 1991.

Franke, H. D., Buchholz, F., and Wiltshire, K. H.: Ecological longterm research at Helgoland (German Bight, North Sea): retrospect and prospect - an introduction, Helgoland Mar. Res., 58, 223-229, 2004.

Fuhrman, J. A. and Azam, F.: Thymidine incorporation as a measure of heterotrophic bacterioplankton production in marine surface waters: evaluation and field results, Mar. Biol., 66, 109-120, 1982.

GARGAS, E.: A manual for phytoplankton primary production studies in the Baltic, BMB publications No. 2, 1975.

Gasol, J. M., delGiorgio, P. A., and Duarte, C. M.: Biomass distribution in marine planktonic communities, Limnol. Oceanogr., 42, 1353-1363, 1997.

Gerdts, G., Wichels, A., Döpke, H., Klings, K. W., Gunkel, W., and Schütt, C.: 40-year long-term study of microbial parameters near Helgoland (German Bight, North Sea): historical view and future perspectives, Helgoland Mar. Res., 58, 230-242, 2004.

Gustafsson, B. G.: Quantification of water, salt, oxygen and nutrient exchange of the Baltic Sea from observations in the Arkona Basin, Cont. Shelf Res., 21, 1485-1500, 2001.

Hansen, H. P. and Koroleff, F.: Determination of nutrients, in: Methods of Seawater Analysis, 3rd Edn., edited by: Grasshoff, K., Kremling, K., and Ehrhardt, M., Wiley VCH, Weinheim, 159228, 1999.

Hansen, H. P., Giesenhagen, H. C., and Behrends, G.: Seasonal and long-term control of bottom water oxygen deficiency in a stratified shallow-coastal system, ICES J. Mar. Sci. Suppl., 56, 65-71, 1999. 
HELCOM: Guidelines for the Baltic monitoring programme for the second stage, Balt. Sea Environ. Proc., No. 12, 1983.

HELCOM: Second Periodic Assessment of the State of the Marine Environment of the Baltic Sea, 1984-1988; General Conclusions, Balt. Sea Environ. Proc., No. 35 A, 1990.

HELCOM: Third Biological Intercalibration Workshop, 27-31 August 1990, Visby, Sweden, Balt. Sea Environ. Proc., No. 38, 1991.

HELCOM: Climate Change in the Baltic Sea Area, Draft HELCOM Thematic Assessment in 2006, HELCOM Stakeholder Conference on the Baltic Sea Action Plan, Helsinki, Finland, 2006.

HELCOM: Climate Change in the Baltic Sea Area - HELCOM thematic assessment 2007, Balt. Sea Environ. Proc., No. 111, 2007.

HELCOM: Eutrophication in the Baltic Sea - an integrated thematic assessment of the effects of nutrient enrichment and eutrophication in the Baltic Sea region: executive summary, Balt. Sea Environ. Proc., No. 115A, 1-19, 2009a.

HELCOM: Eutrophication in the Baltic Sea - an integrated thematic assessment of the effects of nutrient enrichment and eutrophication in the Baltic Sea region, Balt. Sea Environ. Proc., No. 115B, 2009 b.

Hobbie, J. E., Daley, R. J., and Jasper, S.: Use of Nuclepore filters for counting bacteria by fluorescence microscopy, Appl. Environ. Microb., 33, 1225-1228, 1977.

Hoppe, H. G., Breithaupt, P., Walther, K., Koppe, R., Bleck, S., Sommer, U., and Jürgens, K.: Climate warming in winter affects the coupling between phytoplankton and bacteria during the spring bloom: a mesocosm study, Aquat. Microb. Ecol., 51, 105115, 2008.

Kähler, P.: Eutrophication and sediment denitrification in coastal marine waters, the example of Kiel Bight, Kieler Meeresforsch., 56, 112-116, 1991.

Krey, J., Babenerd, B., and Lenz, J.: Beobachtungen zur Produktionsbiologie des Planktons in der Kieler Bucht: 1957-1975, 1. Datenband, Berichte aus dem Institut für Meereskunde an der Christian-Albrechts-Universität Kiel, Germany, 54, 1978.

Lehmann, A., Getzlaff, K., and Harlaß, J.: Detailed assessment of climate variability in the Baltic Sea area for the period 1958 to 2009, Clim. Res., 46, 185-196, 2011.

Naqvi, S. W. A., Bange, H. W., Farãas, L., Monteiro, P. M. S., Scranton, M. I., and Zhang, J.: Marine hypoxia/anoxia as a source of $\mathrm{CH}_{4}$ and $\mathrm{N}_{2} \mathrm{O}$, Biogeosciences, 7, 2159-2190, doi:10.5194/bg7-2159-2010, 2010.

Nausch, G., Bachor, A., Petenati, T., Voß, J., and von Weber, M.: Nutrients in the German coastal waters of the Baltic Sea and adjacent areas, Meeresumwelt aktuell Nord und Ostsee, 1, 1-15, 2011a.

Nausch, G ., Feistel, R., Umlauf, L., Mohrholz, V., and Siegel, H.: Hydrographisch-chemische Zustandseinschätzung der Ostsee 2010, Meereswiss. Ber. Warnemünde, 84, 1-109, 2011 b.

Rheinheimer, G.: Ökologische Untersuchungen zur Nitrifikation in der Nord- und Ostsee, Helgoland Mar. Res., 15, 243-252, 1967.

Schmaljohann, R.: Methane dynamics in the sediment and water column of Kiel Harbour (Baltic Sea), Mar. Ecol. Prog. Ser., 131, 262-273, 1996.

Schneider, B.: The $\mathrm{CO}_{2}$ system of the Baltic Sea: biogeochemical control and impact of anthropogenic $\mathrm{CO}_{2}$, Global Change Balt. Coast. Z., 1, 33-49, 2011.
Simon, M. and Azam, F.: Protein content and protein synthesis rates of planktonic marine bacteria, Mar. Ecol.-Prog. Ser., 51, 201213, 1989.

Smetacek, V.: The annual cycle of Kiel Bight plankton: a long-term analysis, Estuaries, 8, 145-157, 1985.

Turley, C., Blackford, J., Widdicombe, S., Lowe, D., Nightingale, P. D., and Rees, A. P.: Reviewing the impact of increased atmospheric $\mathrm{CO}_{2}$ on oceanic $\mathrm{pH}$ and the marine ecosystem, in: Avoiding Dangerous Climate Change, 8th edn., edited by: Schellnhuber, H. J., Cramer, W., Nakicenovic, N., Wigley, T., and Yohe, G., Cambridge University Press, 65-70, 2006.

Voss, M., Dippner, J. W., Humborg, C., Hürdler, J., Korth, F., Neumann, T., Schernewski, G., and Venohr, M.: History and scenarios of future development of Baltic Sea eutrophication, Estuar. Coast. Shelf. S., 92, 307-322, 2011.

Vuorinen, I., Hänninen, J., Viitasalo, M., Helminen, U., and $\mathrm{Ku}$ osa, H.: Proportion of copepod biomass declines with decreasing salinity in the Baltic Sea, ICES J. Mar. Sci., 55, 767-774, 1998.

Wasmund, N., Pollehne, F., Postel, L., Siegel, H., and Zettler, M. L.: Biologische Zustandseinschätzung der Ostsee im Jahre 2005, Meereswiss. Ber. Warnemünde, 69, 1-69, 2006.

Wasmund, N., Göbel, J., and von Bodungen, B.: 100-years changes in the phytoplankton community of Kiel Bight (Baltic Sea), J. Marine Syst., 73, 300-322, 2008.

Wasmund, N., Schöppe, C., Göbel, J., and von Weber, M.: Chlorophyll $a$ in den deutschen Ostseegewässern, Meeresumwelt Aktuell Nord- und Ostsee, 2, 1-8, 2011a.

Wasmund, N., Tuimala, J., Suikkanen, S., Vandepitte, L., and Kraberg, A.: Long- term trends in phytoplankton composition in the western and central Baltic Sea, J. Marine Syst., 87, 145-159, doi:10.1016/j.jmarsys.2011.03.010, 2011b.

Weigelt, M.: Oxygen conditions in the deep water of Kiel Bay and the impact of inflowing salt-rich water from the Kattegat, Meeresforschung, 33, 1-22, 1990.

Weigelt, M.: Short- and long-term changes in the benthic community of deeper parts of Kiel Bay (Western Baltic) due to oxygen depletion and eutrophication, Meeresforschung, 33, 197224, 1991.

Wild, M., Gilgen, H., Roesch, A., Ohmura, A., Long, C. N., Dutton, E. G., Forgan, B., Kallis, A., Russak, V., and Tsvetkov, A.: From dimming to brightening: decadal changes in solar radiation at earth's surface, Science, 308, 847-850, 2005.

Wiltshire, K. H., Kraberg, A., Bartsch, I., Boersma, M., Frabke, H. D., Freund, J., Gebühr, C., Gerdts, G., Stockmann, K., and Wichels, A.: Helgoland roads, North Sea: 45 years of change, Estuar. Coast., 33, 295-310, 2010.

Wikner, J.: Bacterioplankton growth, Gulf of Bothnia, HELCOM indicator fact sheets 2011, available at: http://www.helcom.fi/BSAP_assessment/ifs/ifs2011/en_GB/ bacterioplankton/?u4.highlight=bacteria, 2011.

Wohlers, J., Engel, A., Zöllner, E., Breithaupt, P., Jürgens, K., Hoppe, H.-G., Sommer, U., and Riebesell, U.: Changes in biogenic carbon flow in response to sea surface warming, P. Natl. Acad. Sci. USA, 106, 7067-7072, 2009.

Zöllner, E., Hoppe, H.-G., Sommer, U., and Jürgens, K.: Effect of zooplankton-mediated trophic cascades on marine microbial food web components (bacteria, nanoflagellates, ciliates), Limnol. Oceanogr. 54, 262-275, 2009. 